4 norden 



\section{Characterisation of waste in relation to the EU acceptance criteria for landfilling}




\section{Characterisation of waste in relation to the EU acceptance criteria for landfilling}

TemaNord 2006:595

(C) Nordic Council of Ministers, Copenhagen 2006

ISBN 978-92-893-1441-1

Copies: Print-on-Demand

This publication can be ordered on www.norden.org/order. Other Nordic publications are available at www.norden.org/publications

Nordic Council of Ministers

Store Strandstræde 18

DK-1255 Copenhagen K

Phone (+45) 33960200

Fax (+45) 33960202

www.norden.org

\section{Nordic Council}

Store Strandstræde 18

DK-1255 Copenhagen K

Phone (+45) 33960400

Fax (+45) 33111870

\section{Nordic Environmental Co-operation}

The Nordic Environmental Action Plan 2005-2008 forms the framework for the Nordic countries' environmental co-operation both within the Nordic region and in relation to the adjacent areas, the Arctic, the EU and other international forums. The programme aims for results that will consolidate the position of the Nordic region as the leader in the environmental field. One of the overall goals is to create a healthier living environment for the Nordic people.

\section{Nordic co-operation}

Nordic co-operation, one of the oldest and most wide-ranging regional partnerships in the world, involves Denmark, Finland, Iceland, Norway, Sweden, the Faroe Islands, Greenland and Åland. Cooperation reinforces the sense of Nordic community while respecting national differences and similarities, makes it possible to uphold Nordic interests in the world at large and promotes positive relations between neighbouring peoples.

Co-operation was formalised in 1952 when the Nordic Council was set up as a forum for parliamentarians and governments. The Helsinki Treaty of 1962 has formed the framework for Nordic partnership ever since. The Nordic Council of Ministers was set up in 1971 as the formal forum for co-operation between the governments of the Nordic countries and the political leadership of the autonomous areas, i.e. the Faroe Islands, Greenland and Åland. 


\section{Content}

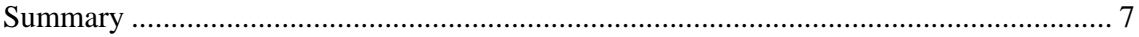

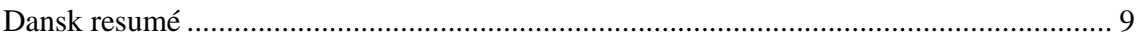

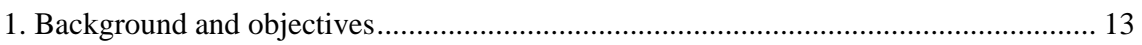

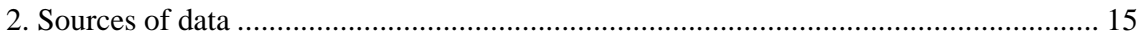

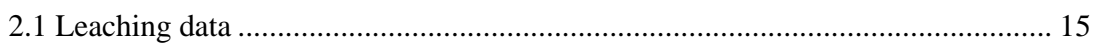

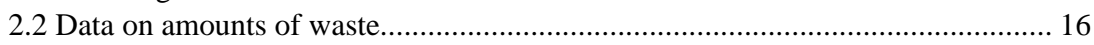

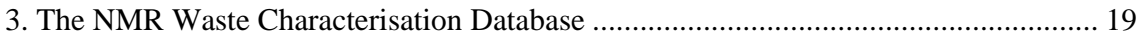

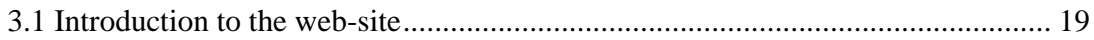

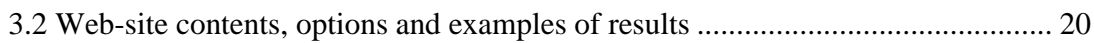

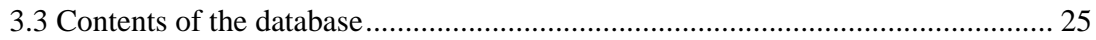

4. Preliminary classification of Nordic waste types in relation to landfill categories ....... 29

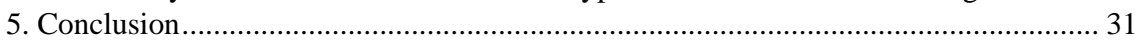

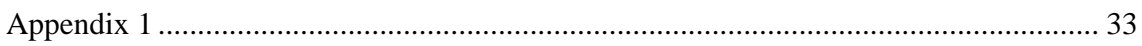

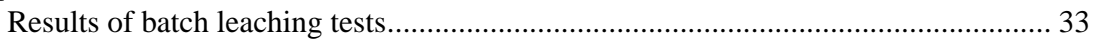





\section{Summary}

A web-based database, the NMR Waste Characterisation Database has been established and made accessible to the members of the NMR Landfill Group. Currently, the database contains approximately 180 datasets consisting of batch and/or column leaching results for the following waste materials:

- C\&D waste: Crushed concrete

- C\&D waste: Crushed concrete \& asphalt

- C\&D waste: Crushed concrete \& tiles

- C\&D waste: Crushed tiles

- C\&D waste: Gypsum plaster boards

- Coal fly ash

- Contaminated soil

- Fly ash from straw firing

- Fly ash from wood chips

- Glass

- Gravel

- Mixed inert container waste

- MSWI APC semidry product

- MSWI APC wet product + FA

- MSWI BA

- MSWI FA

- Road Sweepings

- Shredder waste

- Uncontaminated soil

- "Färskt stoft"

- "Iron sulphate treated matter"

- MSWI FA

- Silica

- Sludge/ash

The number of waste materials and datasets will increase with time.

Via the internet access site, a user can specify country/countries, year(s), waste material type(s), and then select either solid content or leaching. Very few data are at present available on solid content, but several will be added with time. After selecting "Leaching", the user can select parameter(s) of interest (e.g. the parameters for which EU WAC have been set). The user can then choose between batch leaching data and column leaching data. At present, most of the data available are batch leaching results. For batch tests, the data are presented as accumulated 
leached amounts (mg/kg) at L/S = $2 \mathrm{l} / \mathrm{kg}$ and $/$ or $10 \mathrm{l} / \mathrm{kg}$. For column tests, the data are presented as accumulated leached amounts $(\mathrm{mg} / \mathrm{kg})$ at $\mathrm{L} / \mathrm{S}=$ $0.1 \mathrm{l} / \mathrm{kg}, 2 \mathrm{l} / \mathrm{kg}$ and $/$ or $10 \mathrm{l} / \mathrm{kg}$. For each parameter at each L/S value, the data for a given waste material are presented in tables in terms of the number of datasets included, average values, ranges (minimum and maximum values) and median values along with the corresponding EU WAC for landfills for inert waste, landfills for non-hazardous waste receiving stable, non-reactive waste and landfills for hazardous waste. The results obtained may be copied into Excel for further manipulation.

The database is continuously being updated, and new versions are uploaded to the internet at regular intervals. DHI will continue to assign NMR Landfill Group user rights to new data whenever this is appropriate, and the NMR Waste Characterisation Database will therefore continue to grow. Since most of the data currently in the database are Danish, an effort will be made to import waste leaching data from the other Nordic countries when they become available. Within certain limits, this will be carried out by DHI, free of charge. The database will also freely remain accessible to members of the NMR Landfill Group for several years.

To illustrate the potential usefulness of the database, it has been used in its current state to create an indicative classification of several of the waste materials for which data are available. In this exercise, only batch leaching data from Danish waste types was used. Since the evaluation for many materials was based on rather few datasets (in some cases only one dataset) and several parameters for which WAC have been set was missing in several datasets and for several materials, the classification must only be regarded as preliminary and indicative. One somewhat surprising result (based on only one dataset) was that crushed gypsum plaster boards appear to exceed the WAC for hazardous waste landfills for DOC (it would otherwise be acceptable at a landfill for non-hazardous waste).

Database-generated lists of the datasets included in the database at a given time can be made available to the members of the NMR Landfill Group upon request. It will also be possible for NMR Landfill Group members to obtain more detailed information on single waste types to the extent this does not violate the data protection policy of the DHI/C-RES database (e.g. no restrictions on results originating from publicly funded studies). 


\section{Dansk resumé}

Der er etableret en web-baseret database, »NMR Waste Characterisation Database«, som medlemmerne af Nordisk Ministerråds Deponeringsgruppe ved hjælp af brugernavn og password kan logge ind på og benytte via Internettet. Databasen indeholder p.t. ca. 180 datasæt, som består batch- og kolonneudvaskningsresultater for følgende affaldstyper og materialer:

- Bygge- og anlægsaffald: Knust beton

- Bygge- og anlægsaffald: Knust beton og asfalt

- Bygge- og anlægsaffald: Knust beton og tegl

- Bygge- og anlægsaffald: Knust tegl

- Bygge- og anlægsaffald: Knuste gipsplader

- Kulflyveaske

- Kulbundaske

- Flyveaske fra halmfyring

- Flyveaske fra fyring med træflis

- Glas (fra vinduer)

- Stabilt grus

- Blandet inert containeraffald

- Røggasrensningsaffald fra affaldsforbrænding, semitørt produkt (med flyveaske)

- Røggasrensningsaffald fra affaldsforbrænding, slam fra våd proces + flyveaske

- Flyveaske fra affaldsforbrænding

- Slagger/bundaske fra affaldsforbrænding

- Vejopfej

- Shredderaffald

- Uforurenet jord

- »Färskt stoft« (fra Sverige)

- »Materiale behandlet med jernsulfat« (fra Sverige)

- MSWI FA (fra Sverige)

- Silica (fra Sverige)

- Slam/ask (fra Sverige)

Antallet af affaldstyper og antallet af datasæt i databasen øges med tiden.

Via adgangen på Internettet kan en bruger specificere land/lande, perioder (år) og affaldstype(r) og derefter vælge enten »Totalindhold« eller »Stofudvaskning«. P.t. findes der kun få data i databasen vedrørende totalindhold, men flere vil blive lagt ind med tiden. Efter at have valgt „Stofudvaskning « kan brugeren udvælge de parametre, som har interesse 
(f.eks. de parametre, for hvilke der findes EU-kriterier med hensyn til deponering). Brugeren kan derefter vælge mellem batchudvaskningsdata og kolonneudvaskningsdata. For batchudvaskningstests er dataene præsenteret som akkumulerede udvaskede stofmængder (mg/kg) ved L/S = 2 l/kg og/eller $10 \mathrm{l} / \mathrm{kg}$. For kolonneudvaskningstests er dataene præsenteret som akkumulerede udvaskede stofmængder ( $\mathrm{mg} / \mathrm{kg}$ ) ved L/S = 0,1 l/ $/ \mathrm{kg}, 2$ l/kg og/eller 10 l/kg. For hver parameter ved hver L/S-værdi præsenteres dataene for en given affaldstype/et givet materiale i en tabel som antal datasæt inkluderet, middelværdier, variationsbredde (minimums- og maksimumsværdier) og medianværdier sammen med de tilhørende EUgrænseværdier for stofudvaskning ved accept på deponeringsenheder for inert affald, deponeringsenheder for ikke-farligt affald, som modtager stabilt, ikke-reaktivt farligt affald, og deponeringsenheder for farligt affald. Resultaterne kan kopieres til Excel for yderligere behandling, hvis det ønskes.

Databasen opdateres løbende, og nye versioner oploades regelmæssigt på Internettet. DHI vil fortsætte med at give Deponeringsgruppen under NMR brugerrettigheder til nye data, når dette er muligt, og NMR Waste Characterisation Database vil derfor fortsætte med at vokse. Da de fleste af de data, som p.t. findes i databasen, er danske, vil der blive gjort en særlig indsats for at importere udvaskningsdata fra de øvrige nordiske lande, når sådanne bliver tilgængelige. Indenfor rimelige grænser vil dette indledningsvis blive gjort af DHI uden beregning. Databasen vil forblive frit tilgængelig for medlemmerne af Deponeringsgruppen under NMR i en årrække.

For at illustrere den potentielle anvendelighed af databasen er den i sit nuværende omfang blevet brugt til at foretage en indikativ klassificering af en række affaldsmaterialer, for hvilke der findes data i databasen, med hensyn til mulighederne for placering på forskellige deponeringsenheder $\mathrm{i}$ henhold til EU-kriterierne. I denne sammenhæng er der kun anvendt batchudvaskningsdata fra danske affaldstyper. Da vurderingen for mange materialers vedkommende var baseret på forholdsvis få datasæt (i nogle tilfælde kun ét), og da der i mange datasæt mangler udvaskningsdata for en del af parametre, for hvilke der findes EU-kriterier, bør klassificeringen kun betragtes som indledende og indikativ. Et af de måske lidt overraskende resultater af klassificeringen var, at knuste gipsplader for DOC ser ud til at overskride EU-udvaskningskriterierne for modtagelse på en deponeringsenhed for farligt affald (baseret på de øvrige tilgængelige parametre ville gipsen kunne modtages på en deponeringsenhed for ikkefarligt affald). Denne klassificering er dog kun baseret på ét datasæt.

Medlemmerne af Deponeringsgruppen under Nordisk Ministerråd kan på forespørgsel få database-genererede oversigter over de datasæt, som på et givet tidspunkt findes tilgængelige i databasen. De vil også være muligt for gruppens medlemmer at modtage mere information om enkeltaffaldstyper i det omfang dette ikke kompromitterer den gældende data- 
sikkerheds- og beskyttelsespolitik for DHI/C-RES-databasen. For data, der stammer fra offentligt finansierede projekter vil der normalt ikke være nogen restriktioner. 



\section{Background and objectives}

The Nordic countries are currently in the process of implementing and enforcing the EU Landfill Directive (1999/31/EC) and the associated Council Decision of 19 December 2002 establishing criteria and procedures for the acceptance of waste at landfills pursuant to Article 16 and Annex II of Directive 1999/31/EC on the landfill of waste (2003/33/EC). The EU waste acceptance criteria (WAC), which have to be implemented, are primarily based on the results of leaching tests. Only limited and scattered information has been available on the leaching properties of the types on many of the non-hazardous (and hazardous) waste materials expected to be landfilled in the Nordic countries. During the implementation and enforcement of the above mentioned legislation it would be very useful for the responsible authorities in the Nordic countries to have access to as many leaching results on relevant waste materials as possible and to be able to create an overview of the consequences of specific leaching requirements in terms of the compliance of various types of waste with WAC for the various categories of landfills.

The Nordic Council of Ministers has therefore funded a project aimed at the production of tools and data to facilitate the establishment of such an overview. The project has been performed by DHI Water \& Environment, and the NMR Landfill Group under the PA Group has functioned both as an active Steering Committee and as an interactive beta user group.

The main objective of the project has been to provide the authorities and other interested parties in the Nordic countries with information on the likely classification of various types of non-hazardous waste in relation to the categories and sub-categories of landfills defined in Council Decision 2003/33/EC, based on existing leaching data. It has been a further objective to collect such data and make them available to the NMR Landfill Group in the form of a database which can be accessed over the internet.

The project has resulted in two deliverables: One is this report, which provides a brief description of the project work and the database. The report also provides a preliminary classification of a number of waste materials in terms of compliance with the EU WAC for the various categories of landfills. Due to the limited amount of data available at present, this classification is only indicative. The main result of the project is the web-based NMR Waste Characterisation Database, which has been established. The database, which will be updated on a continuous basis, will remain accessible to the members of the NMR Landfill Group. 



\section{Sources of data}

\subsection{Leaching data}

It was originally the intention to collect leaching data for waste materials from all the Nordic countries and make them available in some form in a database which could be accessed by the NMR Landfill Group when needed. It turned out that only a limited amount of data was available, and that data owned by private industry might create data security problems even if they were made anonymous and displayed only in statistical terms. It was therefore decided to use only publicly available data, in particular data from publicly funded studies, including studies funded by the environmental protection agencies in the Nordic countries, and data from data owners who have specifically given permission for their data to be used in this context. It was further decided not to identify single data sets, but only to present data in terms of average and median values as well as minimum and maximum observed values. Most of the data available for use in the database are Danish.

Some of the most important sources of leaching data used in the database so far are listed below:

Hjelmar, O., Holm, P.E., Asmussen, O. \& Isaksen, J. (1998): Karakterisering af affald. Miljøprojekt nr. 414, 1998. Miljø- og Energiministeriet, Miljøstyrelsen, København.

Hjelmar, O. (2002): Karakterisering af restprodukter og jord. Rapport til Miljøstyrelsen udført af DHI. Teknologiudviklingsprogrammet for jordog grundvandsforurening.

Baun, D.L. \& Hjelmar, O. (2003): Kortlægning af forurenende stoffer i byggeaffald. Delrapport til Golder Associates som et led i Miljøstyrelsesprojektet: Kortlægning af forurenende stoffer i byggeaffald.

Hjelmar, O., Holm, J., Crillesen, K. (2006): Utilisation of MSWI bottom ash as sub-base in road construction: First results from a large-scale test site. Journal of Hazardous Materials (in press).

Hjelmar, O., Hansen, J.B., Birch, H. \& Oberender, A. (2006): Opgradering af restprodukter. Slutrapport for stabiliseringsaktiviteter. Udviklingsprojektet ASKEPOT, PSO F\&U 6514. Rapport udarbejdet til Energinet.dk, Energi E2 A/S, I/S Amagerforbrænding og I/S Vestforbrænding. 
Hjelmar, O., Baun, D.L., Ludvigsen, K. \& Rahbek, U. (2006): Karakterisering og behandling af vejopfej. Rapport til Miljøstyrelsen over projekt udført under Miljøstyrelsens program for renere produkter (under publicering).

Hansen, J.B., Hjelmar, O., Oberender, A., Asmussen, O. \& Klem, S. (2006): Testning af danske affaldstyper. Teknisk Notat udført af DHI over undersøgelse for Miljøstyrelsen (under publication).

Lehmann, N., Hjelmar, O. \& Spliid, H. (2000): Stofudvaskning fra jord. Metodeudvikling. Rapport til Miljøstyrelsen udført af DHI i samarbejde med Institut for Matematisk Modellering, DTU. Teknologiudviklingsprogrammet for jord- og grundvandsforurening.

DHI's database: Results of tests performed on bottom ash from Danish municipal solid waste incinerators (kindly made available by the data owners for statistical interpretation).

In addition, specific leaching data on 5 different waste types were received from Naturvårdsverket. These data have been added to the database.

It should be mentioned that the Swedish Geotechnical Institute (SGI) in co-operation with Geo Innova has produced a report about Swedish waste types that may not comply with the limit values for landfilling at landfills for hazardous waste:

Wadstein, E., Håkansson, K., Tiberg, C. \& Suér, P. (2005): Kritiska deponiavfall - som inte klarar gränsvärden för at deponeras på deponi för farligt avfall. SGI, Varia 555, Linköping. This report may be downloaded from SGI's web-site: www.swedgeo.se

Another potential source of information on leaching data on various types of Swedish combustion residues/acid gas cleaning residues is Värmeforsk's database: ALLASKA. It may be accessed freely at the web address: www.askprogrammet.com/ALASKA/allaska.aspx

\subsection{Data on amounts of waste}

It was also the intention to provide input to the database concerning the amounts of the various types of non-hazardous waste produced in the Nordic countries. However, it turned out to be difficult to get reliable data on more than a few types of waste, mainly because the national waste statistics are not sufficiently detailed to be useful in this context. It was 
decided not to pursue this is issue further at present (only data for municipal solid waste incinerator bottom ash (MSWI BA) production in Denmark are currently available in the database (derived from the annual waste statistics published by Miljøstyrelsen in Denmark. However, relevant waste production data from all the Nordic countries may be added later as they may become available. Alternatively, links may be added to other web-sites that might have this information. 



\section{The NMR Waste Characterisation Database}

\subsection{Introduction to the web-site}

The NMR Waste Characterisation Database is based on the DHI/C-RES database which currently contains information on leaching properties and in many cases also composition of approximately 500 waste and soil samples characterised by DHI during the past 10 to 15 years. During the project, data from the sources described in chapter 2 have been incorporated into the database and together with some of the data already in the database made accessible to the NMR Landfill Group via a web-site. The web-site then allows the user to search for information on the various waste types available.

The web-site has the address: http://projects.dhi.dk/c-res/nordic.asp. When this address is entered into the internet browser, the web-page shown in figure 3.1 appears. The members of the NMR Landfill Group have received a user ID and a password which will allow them to log in and access the database.

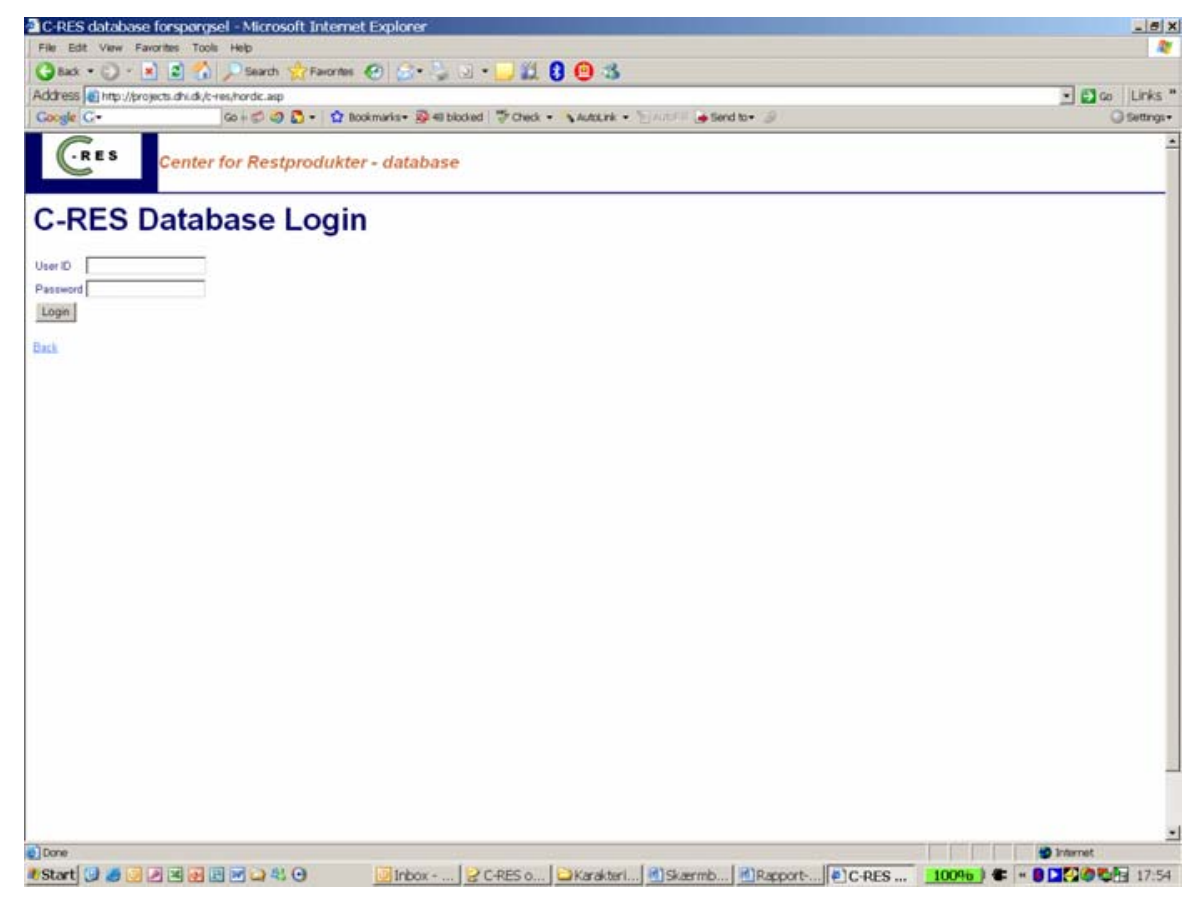

Figure 3.1 Appearance of log-in web-page for the database. 


\subsection{Web-site contents, options and examples of results}

Once the database is accessed, the web-page shown in figure 3.2 will appear. It requires the user to choose between "Show annual amounts of waste" and "Show characteristics". Step-by-step instructions will appear and remain on the right half of the web-page.

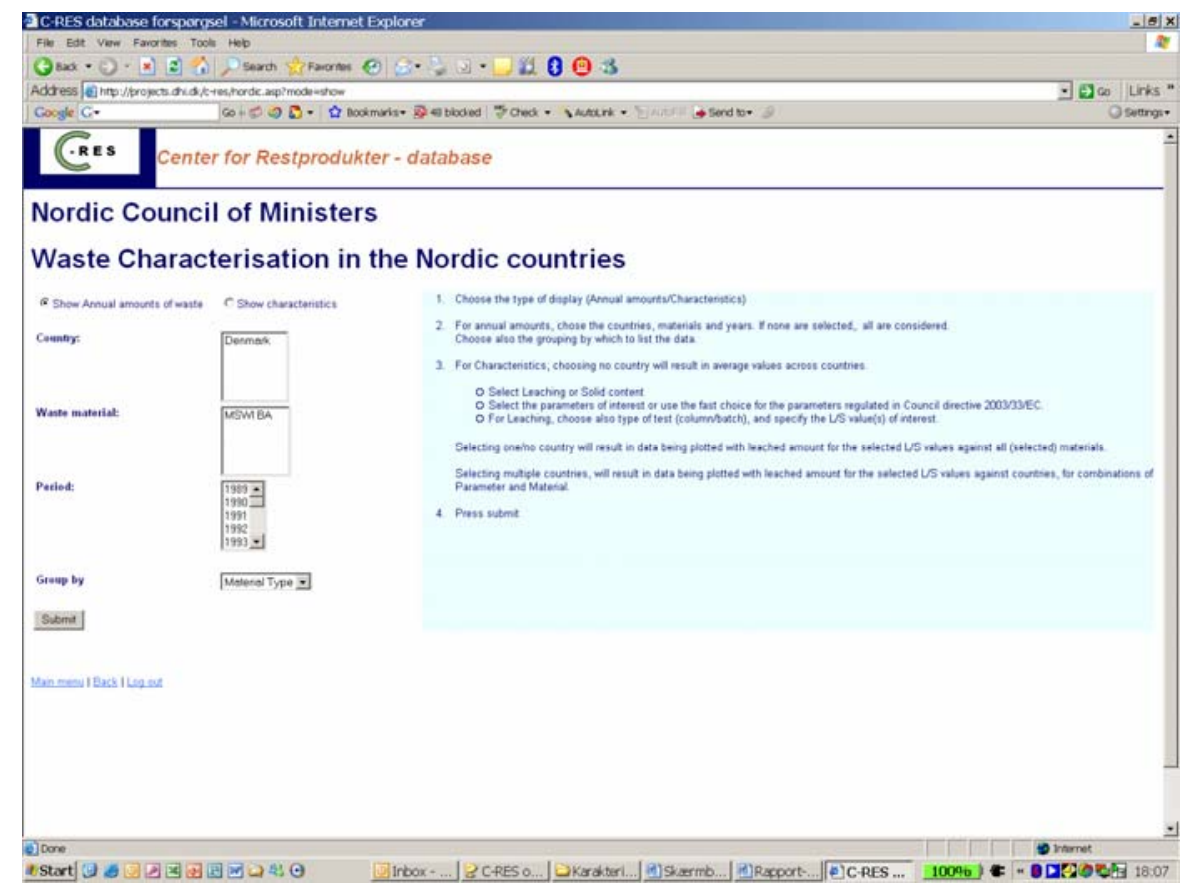

Figure 3.2 Start-page showing the "Show annual amounts of waste"-option.

As already mentioned in section 2.2, very limited data are available at this time on the amounts of different waste types produced. The site allows the user to choose country (one or several of the Nordic countries), waste material(s) and period(s) and subsequently to choose to have the results grouped by (waste) material type, country or year and shown in a table.

A request for the amount of municipal solid waste incinerator bottom ash (MSWI BA) produced in Denmark during the years 1996 to 2004 results, as an example, in the table shown in figure 3.3.

It the "Show characteristics" mode is chosen, the web-site shown in figure 3.4 will appear. Again, the user can choose between the countries available (here only Denmark is possible, but more of the Nordic countries will eventually appear). In general, if no choice is made in a menu, all possibilities are automatically selected. The next choice to be made is the type of material(s) to be considered. The menu will show all waste types available for this purpose. Then the period(s) (year(s)) of production/testing of the waste materials under consideration have to be selected 
(as mentioned above, no selection means that all years will be included in the choice).

In the characteristics mode, a selection has to be made between Leaching data and Solid content data. If Leaching is chosen, it is then necessary to choose the parameters of interest. These can be chosen one by one from the menu (keep the ctr key down during multiple selections) or by using one of the fast choices shown to the left. The first fast choice option selects the parameters for which limit values for landfilling have been set in Council Decision 2003/33/EC. The second fast choice option simply selects all of the parameters listed in the menu.

The next option is a choice between results of column leaching tests or batch leaching tests (to be ticked off). If "Column tests" is chosen, then results (in terms of accumulated leached amounts in $\mathrm{mg} / \mathrm{kg}$ ) at $\mathrm{L} / \mathrm{S}=0.1$ $\mathrm{l} / \mathrm{kg}$ and $/$ or $\mathrm{L} / \mathrm{S}=2 \mathrm{l} / \mathrm{kg}$ and $/$ or $\mathrm{L} / \mathrm{S}=10 \mathrm{l} / \mathrm{kg}$ may be chosen, also by ticking off. If "Batch tests" is chosen, then results (also in terms of accumulated leached amounts in $\mathrm{mg} / \mathrm{kg}$ ) at $\mathrm{L} / \mathrm{S}=2 \mathrm{l} / \mathrm{kg}$ and $/ \mathrm{or} \mathrm{L} / \mathrm{S}=10 \mathrm{l} / \mathrm{kg}$ may be chosen. Finally the box "Include statistics" should always be ticked off. Originally, the site was focused on showing graphs of leaching results by country. It has turned out, however, that the most useful presentations are tables with statistical information on the chosen materials. The graphical presentation has therefore been somewhat suppressed, but it is still possible to see it by clicking on "show/hide" on the web-page presenting the results. When all choices are made, the user must click on the "Submit" button to execute the desired job. 


\section{- R E S Center for Restprodukter - database}

$\begin{array}{ll}\text { Country } & \text { Denmark } \\ \text { Waste Material } & \text { MSWI BA } \\ \text { Period } & \text { 1996, 1997, 1998, 1999, 2000, 2001, 2002, 2003, 2004 } \\ \text { Show by } & \text { Material } \\ \text { Statistics } & \text { NO }\end{array}$

\section{MSWI BA}

Amounts in

tonnes/year

\begin{tabular}{|r|r|}
\hline Year & Denmark \\
\hline 1996 & 509200 \\
\hline 1997 & 493800 \\
\hline 1998 & 468500 \\
\hline 1999 & 519479 \\
\hline 2000 & 494055 \\
\hline 2001 & 465607 \\
\hline 2002 & 543254 \\
\hline 2003 & 644626 \\
\hline 2004 & 564313 \\
\hline
\end{tabular}

Figure 3.3 Result of request for the amounts of MSWI bottom ash produced in Denmark 1996-2004.

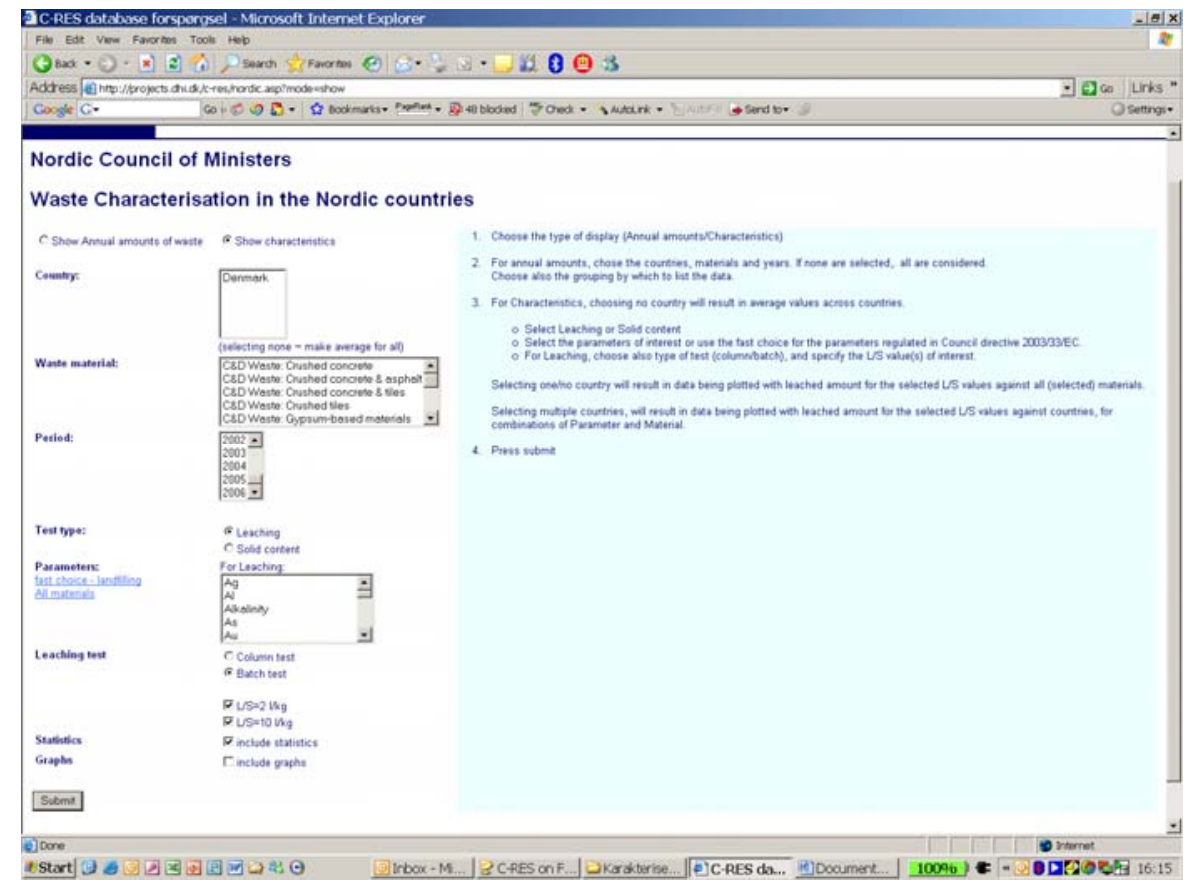

Figure 3.4 Web-page appearing when "Show characteristics", "Leaching" and "Batch test" is chosen.

Figure 3.5 shows an example of the first part of the results from a request. First, all the choices made are listed, enabling the user to check if they are in accordance with the intentions. In this case, the user wants to see all column leaching results for MSWI BA at all three L/S values for all 
countries and all years for the parameters $\mathrm{As}, \mathrm{Ba}$, chloride, $\mathrm{Cr}, \mathrm{Cu}, \mathrm{Na}, \mathrm{Pb}$ and $\mathrm{Sb}$. The first table presents for each parameter for $\mathrm{L} / \mathrm{S}=2 \mathrm{l} / \mathrm{kg}$ the number of samples found, the average value, the minimum and maximum values found and the median value.

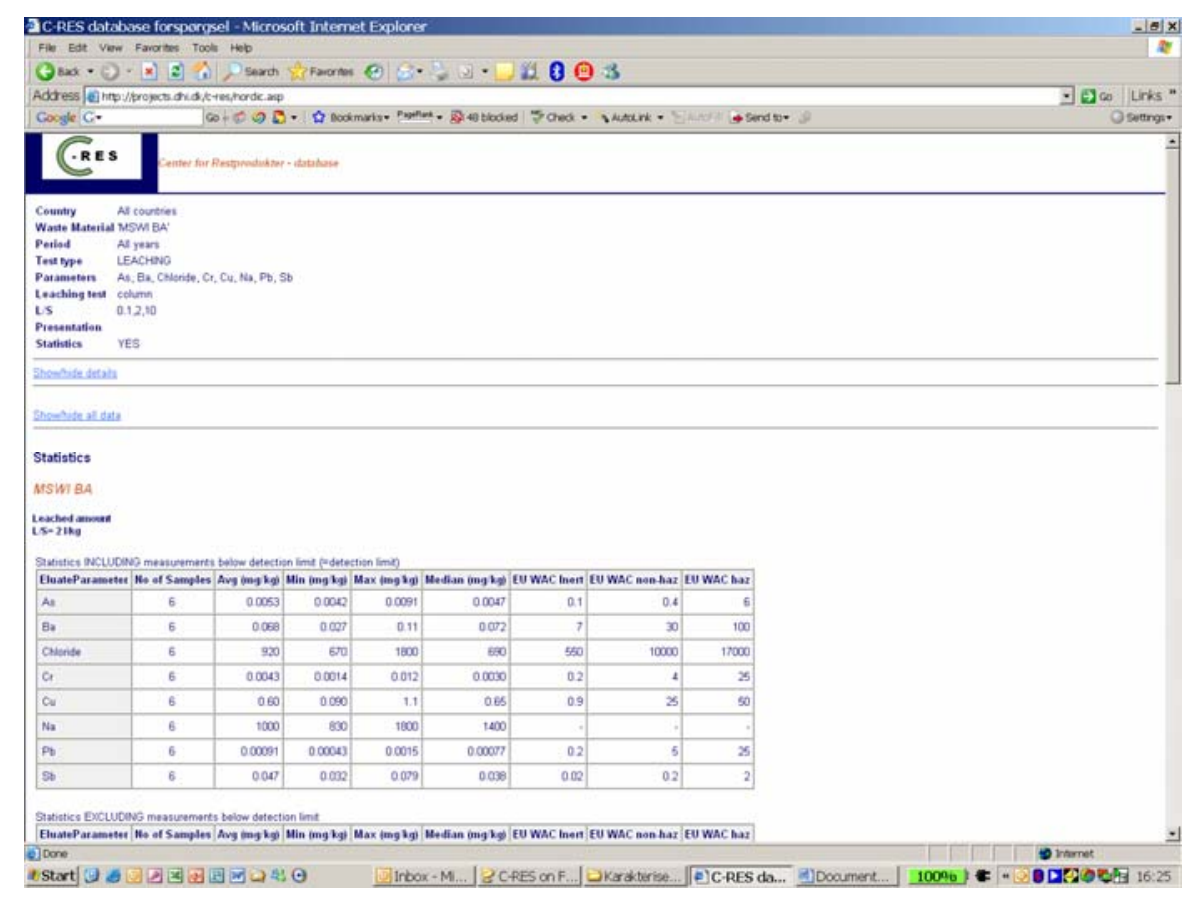

Figure 3.5 Example of results: The first part of request for column leaching data on MSWI BA.

The table further shows the EU waste acceptance criteria (WAC) for inert waste landfills, landfills for non-hazardous waste accepting stable, nonreactive hazardous waste, and landfills for hazardous waste, according to Council Decision 2003/33/EC.

Figure 3.6 shows the same response as figure 3.5, scrolled down a litthe further. Two tables are now shown with results for column tests on MSWI BA at L/S = $2 \mathrm{l} / \mathrm{kg}$. When treating data based on chemical analyses it is always a problem to decide how to handle results below the limit of detection. Should they be included or excluded? In this case it has been decided to treat the data in two different ways: In the first table, results below the detection limit have been included with the value of such data set equal to the detection limit. In the second table, all data based on analytical results below the detection limit have been excluded. It can be seen that whereas the number of samples in the first table is 6 for all parameters, it has changed to 5 for $\mathrm{As}$ and $\mathrm{Cr}$, and to $3 \mathrm{for} \mathrm{Pb}$ in the second table in figure 3.6, indicating that 1 and 3 results, respectively, is below the limit of detection. The same web-page shows similar results of column tests on MSWI BA at $\mathrm{L} / \mathrm{S}=0.1 \mathrm{l} / \mathrm{kg}$ and $\mathrm{L} / \mathrm{S}=10 \mathrm{l} / \mathrm{kg}$. 
In many leaching tests, the $\mathrm{L} / \mathrm{S}$ values are not exactly $0.1,2$ or $10 \mathrm{l} / \mathrm{kg}$, they may for various reasons be a little off the intended values. In this context, the values chosen are rounded values, i.e. they are chosen from values between 0.050 and $0.149 \mathrm{l} / \mathrm{kg}, 1.50$ and $2.49 \mathrm{l} / \mathrm{kg}$ and 9.50 and $10.49 \mathrm{l} / \mathrm{kg}$. The same applies to results for batch leaching tests.

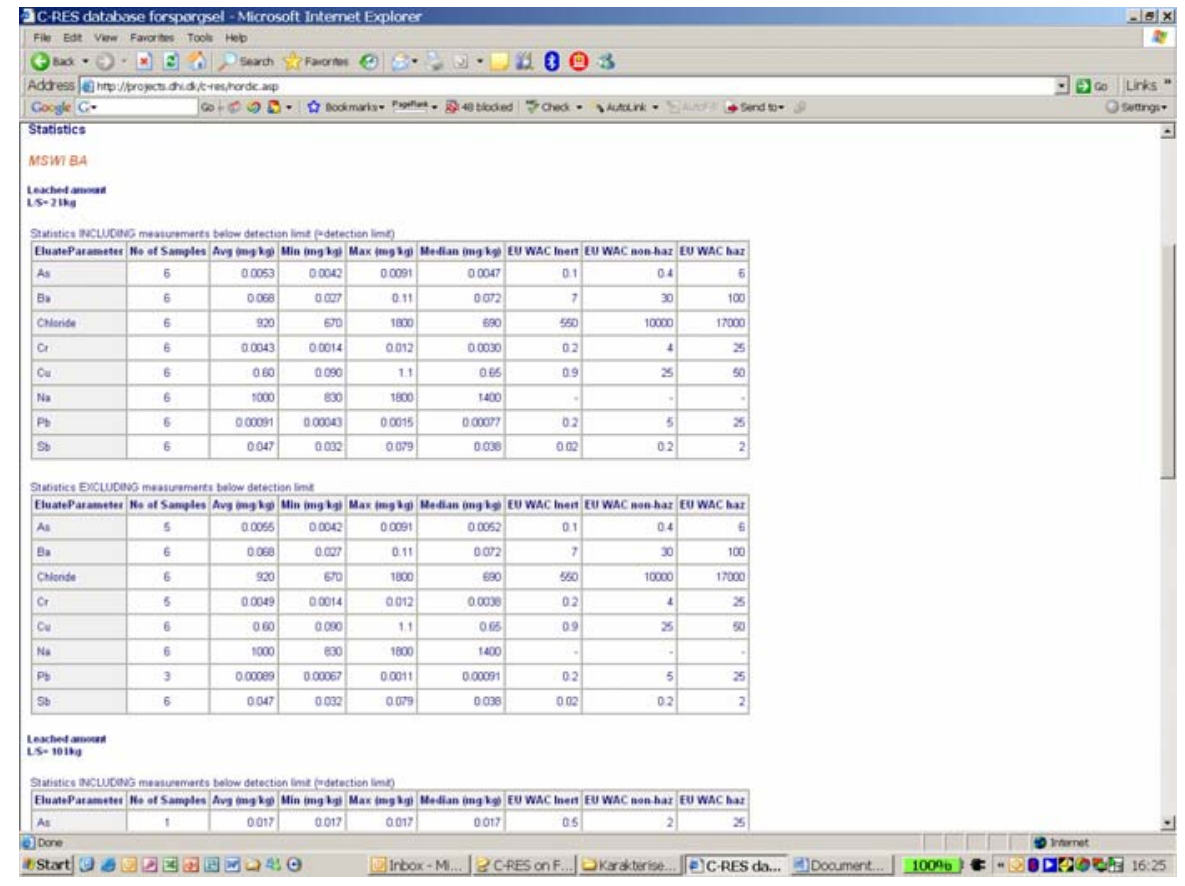

Figure 3.6 Example of results: Column leaching data for MSWI BA at $\mathrm{L} / \mathrm{S}=2 \mathrm{l} / \mathrm{kg}$ including and excluding data based on chemical analytical results below the limit of detection.

Figure 3.7 shows results of a request for all available batch leaching test results for MSWI BA at $\mathrm{L} / \mathrm{S}=2 \mathrm{l} / \mathrm{kg}$ for all the parameters for which EU criteria for acceptance at landfills have been set (only data with limit values included are shown here). As can be seen, the database available to the NMR Landfill Group currently contains results for at least 70 samples of MSWI bottom ash for some parameters, whereas the number of results for other parameters is more limited (down to 5 for TDS, total dissolved solids).

Figure 3.7 also illustrates the manner in which $\mathrm{pH}$ data are managed in the system. The calculation of average values of the logarithmic parameter, $\mathrm{pH}$, is not very meaningful or useful. It has therefore been decided to show $\mathrm{pH}$ separately in terms of a range of values (minimum and maximum values) in the upper right part of the page. 


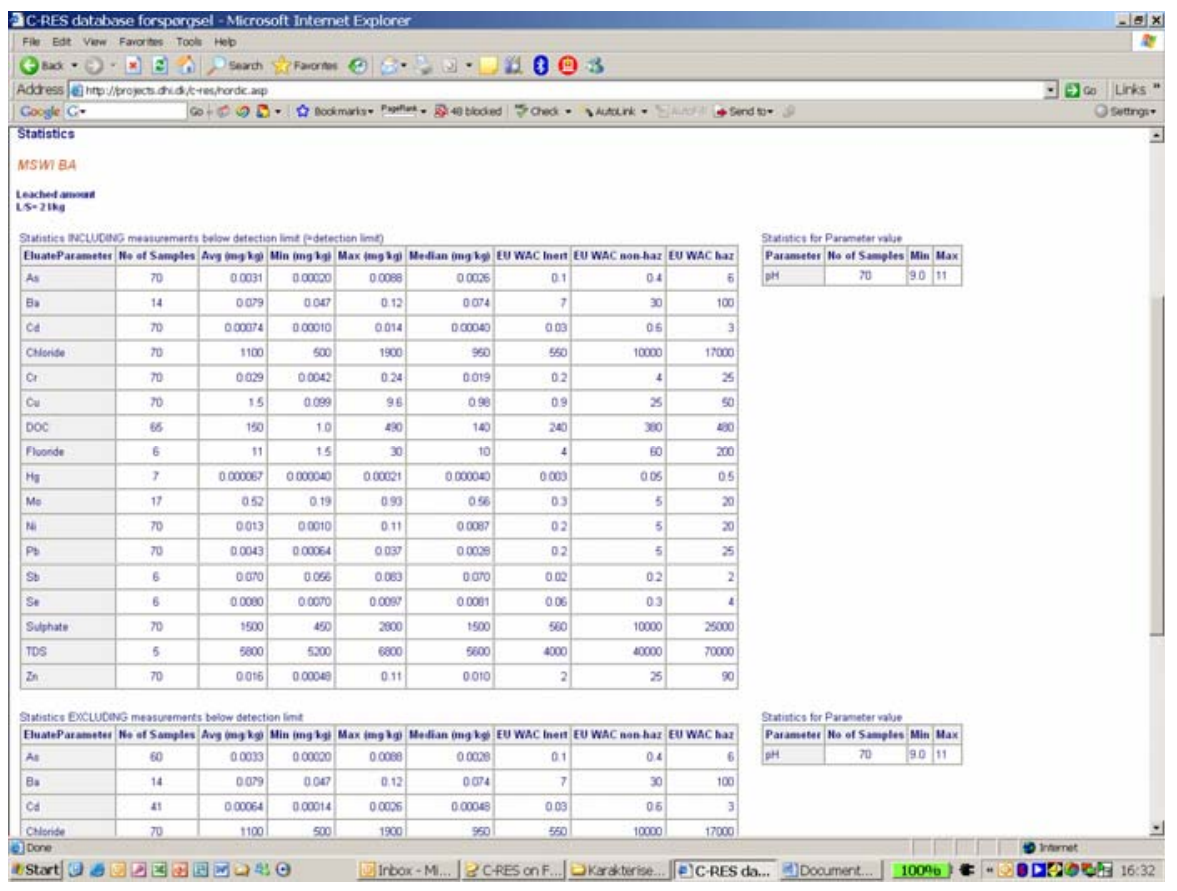

Figure 3.7 Example of results: Batch leaching data for MSWI BA at $L / S=2 \mathrm{l} / \mathrm{kg}$ for all parameters for which EU WAC have been set.

If "Solid content" is chosen in the menu shown on figure 3.4, it is possible to select parameters in the same manner as for "Leaching". However, no data on solid content are currently available in this database. Due to the fact that no total content WAC exist for landfills for non-hazardous and hazardous waste, leaching data have been given highest priority in establishing the database. WAC for total content may eventually be established at national level, and total content data will be incorporated into the database as they are produced.

It should be noted that results may be copied to Excel for further manipulation.

\subsection{Contents of the database}

The NMR Waste Characterisation Database consists of a segment of the DHI/C-RES database, which has been made available to the NMR Landfill Group by adding specific data and by assigning Landfill Group user rights both to new and to existing data fulfilling the criteria mentioned in section 2.1. The DHI/C-RES database is continuously being updated, and new versions are uploaded to the internet at regular intervals. DHI will continue to assign NMR Landfill Group user rights to new data whenever this is appropriate, and the NMR Waste Characterisation Database will therefore continue to grow. Since most of the data currently in the database are Danish, an effort will be made to import waste leaching data 
from the other Nordic countries when they become available. Within certain limits, this will be carried out by DHI, free of charge. The database will also freely remain accessible to members of the NMR Landfill Group for several years.

At the end of August 2006 the data shown in table 3.1 (Danish) and 3.2 (Swedish) are included in the NMR Waste Characterisation Database:

Table 3.1 Danish leaching data currently in the NMR Waste Characterisation Database.

\begin{tabular}{|c|c|c|c|c|c|c|}
\hline \multirow{3}{*}{ Waste } & \multirow{3}{*}{ EWC code } & \multicolumn{4}{|c|}{ Number of datasets } & \multirow[b]{3}{*}{$10 \mathrm{l} / \mathrm{kg}$} \\
\hline & & \multicolumn{2}{|c|}{ Batch tests (L/S) } & \multicolumn{2}{|c|}{ Column tests (L/S) } & \\
\hline & & $2 \mathrm{l} / \mathrm{kg}$ & $10 \mathrm{l} / \mathrm{kg}$ & $0.1 \mathrm{l} / \mathrm{kg}$ & $21 / \mathrm{kg}$ & \\
\hline C\&D waste: Crushed concrete & 170101 & 3 & & & & \\
\hline $\begin{array}{l}\text { C\&D waste: Crushed concrete \& } \\
\text { asphalt }\end{array}$ & 170302 & 1 & & & & \\
\hline C\&D waste: Crushed concrete \& tiles & 170107 & 2 & & & & \\
\hline C\&D waste: Crushed tiles & 170103 & 1 & & & & \\
\hline C\&D waste: Gypsum plaster boards & 170802 & 1 & $(1)$ & & & \\
\hline Coal bottom ash & 100101 & (1) & (1) & (1) & (1) & \\
\hline Coal fly ash & 100102 & $(2)$ & & & & \\
\hline Contaminated soil & $170504 / 03$ & 10 & & (2) & (2) & \\
\hline Fly ash from straw firing & 100199 & (1) & (1) & & & \\
\hline Fly ash from wood chips & 100199 & $(1)$ & (1) & & & \\
\hline Glass & 170202 & 1 & (1) & & & \\
\hline Gravel & 170504 & $(1)$ & (1) & & & \\
\hline Mixed inert container waste & 191212 & 3 & (3) & & & \\
\hline MSWI APC semidry product & 190107 & & 8 & 1 & 1 & 1 \\
\hline MSWI APC wet product + FA & 190107 & 1 & 1 & & & \\
\hline MSWI BA & 190112 & 71 & $(1)$ & $6+(1)$ & $6+(1)$ & 6 \\
\hline MSWI FA & 1901 13/14 & & 5 & 1 & 1 & 1 \\
\hline Road Sweepings & 200303 & 14 & $(6)$ & & & \\
\hline $\begin{array}{l}\text { Shredder waste } \\
\text { Uncontaminated soil }\end{array}$ & 190208 & (1) & & (1) & (1) & (1) \\
\hline
\end{tabular}

Numbers in parentheses: datasets undergoing quality control, soon to be admitted into the database

Table 3.2 Swedish leaching data currently in the NMR Waste Characterisation Database.

\begin{tabular}{|c|c|c|c|c|c|c|}
\hline \multirow{3}{*}{ Waste } & \multirow{3}{*}{ EWC code } & \multicolumn{4}{|c|}{ Number of datasets } & \multirow[b]{3}{*}{$10 \mathrm{l} / \mathrm{kg}$} \\
\hline & & \multicolumn{2}{|c|}{ Batch tests (L/S) } & \multicolumn{2}{|c|}{ Column tests (L/S) } & \\
\hline & & $2 \mathrm{l} / \mathrm{kg}$ & $10 \mathrm{l} / \mathrm{kg}$ & $0.1 \mathrm{l} / \mathrm{kg}$ & $2 \mathrm{l} / \mathrm{kg}$ & \\
\hline "Färsk stoft" & & (1) & (1) & & & \\
\hline "Iron sulphate treated matter" & & & & (1) & (1) & (1) \\
\hline MSWI FA & 1901 13/14 & (1) & (1) & (1) & & (1) \\
\hline Silica & & (1) & (1) & (1) & & (1) \\
\hline Sludge/ash & & (1) & (1) & & & \\
\hline
\end{tabular}

Numbers in parentheses: datasets undergoing quality control, soon to be admitted into the database 
Database-generated lists of the datasets included in the database at a given time can be made available to the members of the NMR Landfill Group upon request. It will also be possible for NMR Landfill Group members to obtain more detailed information on single waste types to the extent this does not violate the data protection policy of the DHI/C-RES database (e.g. no restrictions on results originating from publicly funded studies). 



\section{Preliminary classification of Nordic waste types in relation to landfill categories}

Many of the datasets in the NMR Waste Characterisation Database were produced before the Council Decision 2003/33/EC was developed and many datasets were produced for other reasons than compliance with landfilling regulation. It is therefore not possible at this time to perform a reliable classification of the waste materials in the database in relation to the landfill categories defined in 2003/33/EC and the Landfill Directive (1999/31EC). It is, however, possible for a user of the database to check the amount of data available on a specific type of waste and to decide whether that is sufficient in a given situation. Due to the continuous updating of the database it will become more complete with time and hence more useful in this respect.

To illustrate the potential usefulness of the database, it has been used in its current state to create an indicative classification of several of the waste materials for which data are available. In this exercise, only batch leaching data from Danish waste types have been used. Since the evaluation for many materials is based on rather few datasets (in some cases only one dataset) and several parameters for which WAC have been set are missing in several datasets and for several materials, the classification is only preliminary and indicative.

In Appendix 1 tables like that shown in figure 3.7 have been created for a number of waste materials. A colour code has been used to indicate when the EU limit value for one of the three categories of landfills is exceeded (green for landfills for inert waste, blue for landfills for nonhazardous waste receiving stable, non-reactive hazardous waste and yellow for hazardous waste landfills. The results are summarised in table 4.1. 
Table 4.1 Indicative classification of waste types in the NMR Waste Characterisation Database according to the most like type of landfill for which they would comply with the EU acceptance criteria. Due to insufficient data, the results should be taken only as indicative. $\mathbf{N}=$ number of datasets.

\begin{tabular}{|c|c|c|c|c|}
\hline Waste type & $\mathbf{N}$ & $\begin{array}{l}\text { Parameters not } \\
\text { available* }\end{array}$ & $\begin{array}{l}\text { Likely landfill } \\
\text { classification }\end{array}$ & $\begin{array}{l}\text { Most critical } \\
\text { components } \\
\text { observed }\end{array}$ \\
\hline C\&D waste: Crushed concrete & 3 & $\mathrm{Mo}, \mathrm{Sb}, \mathrm{Se}, \mathrm{F}, \mathrm{DOC}$ & Inert & \\
\hline $\begin{array}{l}\text { C\&D waste: Crushed concrete \& } \\
\text { asphalt }\end{array}$ & 1 & Mo, Sb, Se, F, DOC & Inert & \\
\hline $\begin{array}{l}\text { C\&D waste: Crushed concrete \& } \\
\text { tiles }\end{array}$ & 2 & Mo, Sb, Se, F, DOC & Inert & \\
\hline C\&D waste: Crushed tiles & 1 & $\mathrm{Mo}, \mathrm{Sb}, \mathrm{Se}, \mathrm{F}, \mathrm{DOC}$ & Non-haz & $\mathrm{SO} 4$ \\
\hline C\&D waste: Gypsum plaster boards & 1 & $\begin{array}{l}\mathrm{Ba}, \mathrm{Hg}, \mathrm{Mo}, \mathrm{Sb}, \mathrm{Se} \\
\mathrm{F}\end{array}$ & $\begin{array}{l}\text { Exceeds } \\
\text { Haz }\end{array}$ & DOC \\
\hline Glass (from windows) & 1 & $\begin{array}{l}\mathrm{Ba}, \mathrm{Hg}, \mathrm{Mo}, \mathrm{Sb}, \mathrm{Se} \\
\mathrm{F}\end{array}$ & Inert & \\
\hline Mixed inert container waste & 3 & $\begin{array}{l}\mathrm{Ba}, \mathrm{Hg}, \mathrm{Mo}, \mathrm{Sb}, \mathrm{Se} \\
\mathrm{F}\end{array}$ & Non-haz & $\mathrm{Cr}, \mathrm{Ni}, \mathrm{SO} 4$ \\
\hline MSWI APC semidry product & 4 & DOC & $\begin{array}{l}\text { Exceeds } \\
\text { Haz }\end{array}$ & $\mathrm{Cl}, \mathrm{SO} 4$ \\
\hline MSWI BA & $6-70$ & & Non-haz ${ }^{1)}$ & $\begin{array}{l}\mathrm{Cl}, \mathrm{SO} 4, \mathrm{~F}, \mathrm{Cu}, \\
\mathrm{Mo}, \mathrm{Sb}\end{array}$ \\
\hline MSWI FA & 3 & & $\begin{array}{l}\text { Exceeds } \\
\text { Haz }\end{array}$ & $\mathrm{Cl}, \mathrm{SO} 4$ \\
\hline Road Sweepings & $5-14$ & Mo, Sb, Se, F & Non-haz & $\mathrm{Cl}, \mathrm{Cu}, \mathrm{DOC}$ \\
\hline Uncontaminated soil & $8-31$ & $\begin{array}{l}\mathrm{Ba}, \mathrm{Hg}, \mathrm{Mo}, \mathrm{Sb}, \mathrm{Se} \\
\mathrm{F}, \mathrm{DOC}\end{array}$ & Inert & \\
\hline
\end{tabular}

*: No information on phenol-index is available (only relevant for acceptance at inert waste landfills)

1): Single (non-typical) values of $\mathrm{Cr}$ and DOC exceeds WAC for hazardous waste landfills

It may be slightly surprising that crushed gypsum plaster boards exceeds the WAC for hazardous waste landfills for DOC (it would otherwise be acceptable at a landfill for non-haz waste). 


\section{Conclusion}

A web-based database, the NMR Waste Characterisaition Database has been established and made accessible to the members of the NMR Landfill Group. Currently, the database contains approximately 180 datasets consisting of batch and/or column leaching results for the following waste materials:

- C\&D waste: Crushed concrete

- C\&D waste: Crushed concrete \& asphalt

- C\&D waste: Crushed concrete \& tiles

- C\&D waste: Crushed tiles

- C\&D waste: Gypsum plaster boards

- Coal fly ash

- Contaminated soil

- Fly ash from straw firing

- Fly ash from wood chips

- Glass

- Gravel

- Mixed inert container waste

- MSWI APC semidry product

- MSWI APC wet product + FA

- MSWI BA

- MSWI FA

- Road Sweepings

- Shredder waste

- Uncontaminated soil

- "Färsk stoft"

- "Iron sulphate treated matter"

- MSWI FA

- Silica

- Sludge/ash

To illustrate the potential usefulness of the database, it has been used in its current state to create an indicative classification of several of the waste materials for which data are available. In this exercise, only batch leaching data from Danish waste types was used. Since the evaluation for many materials was based on rather few datasets (in some cases only one dataset) and several parameters for which WAC have been set was missing in several datasets and for several materials, the classification was only preliminary and indicative. One somewhat surprising result (based on only one dataset) was that crushed gypsum plaster boards appear to 
exceed the WAC for hazardous waste landfills for DOC (it would otherwise be acceptable at a landfill for non-haz waste). 


\section{Appendix 1}

Results of batch leaching tests 


\section{Batch leaching test}

\section{C\&D Waste: Crushed concrete}

Leached amount

L/S= $2 \mathrm{l} / \mathrm{kg}$

\begin{tabular}{|c|c|c|c|c|c|c|c|c|}
\hline EluateParameter & $\begin{array}{c}\text { No of } \\
\text { Samples }\end{array}$ & $\begin{array}{c}\text { Avg } \\
(\mathrm{mg} / \mathrm{kg})\end{array}$ & $\begin{array}{c}\text { Min } \\
(\mathrm{mg} / \mathrm{kg})\end{array}$ & $\begin{array}{c}\text { Max } \\
(\mathrm{mg} / \mathrm{kg})\end{array}$ & $\begin{array}{l}\text { Median } \\
(\mathrm{mg} / \mathrm{kg})\end{array}$ & $\begin{array}{c}\text { EU WAC } \\
\text { Inert }\end{array}$ & \begin{tabular}{l|} 
EU WAC \\
non-haz
\end{tabular} & $\begin{array}{c}\text { EU WAC } \\
\text { haz }\end{array}$ \\
\hline As & 3 & 0.0016 & 0.0016 & 0.0016 & 0.0016 & 0.1 & 0.4 & 6 \\
\hline $\mathrm{Ba}$ & 3 & 0.63 & 0.16 & 1.2 & 0.52 & 7 & 30 & 100 \\
\hline $\mathrm{Cd}$ & 3 & 0.0004 & 0.0004 & 0.00041 & 0.00040 & 0.03 & 0.6 & 3 \\
\hline Chloride & 3 & 49 & 24 & 69 & 54 & 550 & 10000 & 17000 \\
\hline $\mathrm{Cr}$ & 3 & 0.07 & 0.032 & 0.091 & 0.088 & 0.2 & 4 & 25 \\
\hline$\overline{\mathrm{Cu}}$ & 3 & 0.032 & 0.018 & 0.051 & 0.026 & 0.9 & 25 & 50 \\
\hline $\mathrm{Hg}$ & 3 & 0.000039 & 0.000031 & 0.000045 & 0.000042 & 0.003 & 0.05 & 0.5 \\
\hline$\widehat{\mathrm{Ni}}$ & 3 & 0.014 & 0.011 & 0.017 & 0.013 & 0.2 & 5 & 20 \\
\hline $\mathrm{Pb}$ & 3 & 0.002 & \begin{tabular}{l|l}
0.002 \\
\end{tabular} & 0.002 & 0.0020 & 0.2 & 5 & 25 \\
\hline Sulphate & 3 & 22 & 9.6 & 39 & 18 & 560 & 10000 & 25000 \\
\hline $\mathrm{Zn}$ & 3 & 0.02 & 0.02 & 0.02 & 0.020 & 2 & 25 & 90 \\
\hline
\end{tabular}

Statistics EXCLUDING measurements below detection limit

\begin{tabular}{|c|c|c|c|c|c|c|c|c|}
\hline EluateParameter & $\begin{array}{c}\text { No of } \\
\text { Samples }\end{array}$ & $\begin{array}{c}\text { Avg } \\
(\mathrm{mg} / \mathrm{kg})\end{array}$ & $\begin{array}{c}\text { Min } \\
(\mathrm{mg} / \mathrm{kg})\end{array}$ & $\begin{array}{c}\text { Max } \\
(\mathrm{mg} / \mathrm{kg})\end{array}$ & $\begin{array}{l}\text { Median } \\
\text { (mg/kg) }\end{array}$ & $\begin{array}{c}\text { EU WAC } \\
\text { Inert }\end{array}$ & $\begin{array}{l}\text { EU WAC } \\
\text { non-haz }\end{array}$ & $\begin{array}{c}\text { EU WAC } \\
\text { haz }\end{array}$ \\
\hline $\mathrm{Ba}$ & 3 & 0.63 & 0.16 & 1.2 & 0.52 & 7 & 30 & 100 \\
\hline Chloride & 3 & 49 & 24 & 69 & 54 & 550 & 10000 & 17000 \\
\hline $\mathrm{Cr}$ & 3 & 0.07 & 0.032 & 0.091 & 0.088 & 0.2 & 4 & 25 \\
\hline $\mathrm{Cu}$ & 3 & 0.032 & 0.018 & 0.051 & 0.026 & 0.9 & 25 & 50 \\
\hline $\mathrm{Hg}$ & 2 & 0.000037 & 0.000031 & 0.000042 & 0.000037 & 0.003 & 0.05 & 0.5 \\
\hline $\mathrm{Ni}$ & 3 & 0.014 & 0.011 & 0.017 & 0.013 & 0.2 & 5 & 20 \\
\hline Sulphate & 3 & 22 & 9.6 & 39 & 18 & 560 & 10000 & 25000 \\
\hline
\end{tabular}

Statistics for Parameter value (for upper table)
\begin{tabular}{|l|c|r|r|}
\hline Parameter & $\begin{array}{c}\text { No of } \\
\text { Samples }\end{array}$ & Min & \multicolumn{1}{|c|}{ Max } \\
\hline $\mathrm{pH}$ & 3 & 12 & 12 \\
\hline
\end{tabular}




\section{Batch leaching test}

\section{C\&D Waste: Crushed concrete \& asphalt}

\section{Leached amount}

L/S= 2 I/kg

\begin{tabular}{|c|c|c|c|c|c|c|c|c|}
\hline EluateParameter & $\begin{array}{c}\text { No of } \\
\text { Samples }\end{array}$ & $\begin{array}{c}\text { Avg } \\
(\mathrm{mg} / \mathrm{kg})\end{array}$ & $\begin{array}{c}\text { Min } \\
(\mathrm{mg} / \mathrm{kg})\end{array}$ & $\begin{array}{c}\text { Max } \\
(\mathrm{mg} / \mathrm{kg})\end{array}$ & $\begin{array}{l}\text { Median } \\
(\mathrm{mg} / \mathrm{kg})\end{array}$ & $\begin{array}{c}\text { EU WAC } \\
\text { Inert }\end{array}$ & $\begin{array}{l}\text { EU WAC } \\
\text { non-haz }\end{array}$ & $\begin{array}{c}\text { EU WAC } \\
\text { haz }\end{array}$ \\
\hline As & 1 & 0.0016 & 0.0016 & 0.0016 & 0.0016 & 0.1 & 0.4 & 6 \\
\hline $\mathrm{Ba}$ & 1 & 0.12 & 0.12 & 0.12 & 0.12 & 7 & 30 & 100 \\
\hline $\mathrm{Cd}$ & 1 & 0.0004 & 0.0004 & 0.0004 & 0.00040 & 0.03 & 0.6 & 3 \\
\hline Chloride & 1 & 180 & 180 & 180 & 180 & 550 & 10000 & 17000 \\
\hline $\mathrm{Cr}$ & 1 & 0.039 & 0.039 & 0.039 & 0.039 & 0.2 & 4 & 25 \\
\hline $\mathrm{Cu}$ & 1 & 0.15 & 0.15 & 0.15 & 0.15 & 0.9 & 25 & 50 \\
\hline $\mathrm{Hg}$ & 1 & 0.000024 & 0.000024 & 0.000024 & 0.000024 & 0.003 & 0.05 & 0.5 \\
\hline $\mathrm{Ni}$ & 1 & 0.024 & 0.024 & 0.024 & 0.024 & 0.2 & 5 & 20 \\
\hline $\mathrm{Pb}$ & 1 & 0.002 & 0.002 & 0.002 & 0.0020 & 0.2 & 5 & 25 \\
\hline Sulphate & 1 & 35 & 35 & 35 & 35 & 560 & 10000 & 25000 \\
\hline $\mathrm{Zn}$ & 1 & 0.02 & 0.02 & 0.02 & 0.020 & 2 & 25 & 90 \\
\hline
\end{tabular}

\begin{tabular}{|c|c|c|c|c|c|c|c|c|}
\hline EluateParameter & $\begin{array}{c}\text { No of } \\
\text { Samples }\end{array}$ & $\begin{array}{c}\text { Avg } \\
(\mathrm{mg} / \mathrm{kg})\end{array}$ & $\begin{array}{c}\text { Min } \\
(\mathrm{mg} / \mathrm{kg})\end{array}$ & $\begin{array}{c}\text { Max } \\
(\mathrm{mg} / \mathrm{kg}) \\
\end{array}$ & $\begin{array}{l}\text { Median } \\
(\mathrm{mg} / \mathrm{kg})\end{array}$ & \begin{tabular}{|c|}
$\begin{array}{c}\text { EU WAC } \\
\text { Inert }\end{array}$ \\
\end{tabular} & $\begin{array}{l}\text { EU WAC } \\
\text { non-haz }\end{array}$ & $\begin{array}{c}\text { EU WAC } \\
\text { haz }\end{array}$ \\
\hline As & 1 & 0.0016 & 0.0016 & 0.0016 & 0.0016 & 0.1 & 0.4 & 6 \\
\hline $\mathrm{Ba}$ & 1 & 0.12 & 0.12 & 0.12 & 0.12 & 7 & 30 & 100 \\
\hline $\mathrm{Cd}$ & 1 & 0.0004 & 0.0004 & 0.0004 & 0.00040 & 0.03 & 0.6 & 3 \\
\hline Chloride & 1 & 180 & 180 & 180 & 180 & 550 & 10000 & 17000 \\
\hline $\mathrm{Cr}$ & 1 & 0.039 & 0.039 & 0.039 & 0.039 & 0.2 & 4 & 25 \\
\hline $\mathrm{Cu}$ & 1 & 0.15 & 0.15 & 0.15 & 0.15 & 0.9 & 25 & 50 \\
\hline $\mathrm{Hg}$ & 1 & 0.000024 & 0.000024 & 0.000024 & 0.000024 & 0.003 & 0.05 & 0.5 \\
\hline $\mathrm{Ni}$ & 1 & 0.024 & 0.024 & 0.024 & 0.024 & 0.2 & 5 & 20 \\
\hline $\mathrm{Pb}$ & 1 & 0.002 & 0.002 & 0.002 & 0.0020 & 0.2 & 5 & 25 \\
\hline Sulphate & 1 & 35 & 35 & 35 & 35 & 560 & 10000 & 25000 \\
\hline $\mathrm{Zn}$ & 1 & 0.02 & 0.02 & 0.02 & 0.020 & 2 & 25 & 90 \\
\hline
\end{tabular}

Statistics for Parameter value (for upper table)
\begin{tabular}{|l|c|c|c|}
\hline Parameter & $\begin{array}{c}\text { No of } \\
\text { Samples }\end{array}$ & Min & Max \\
\hline $\mathrm{pH}$ & 1 & 12 & 12 \\
\hline
\end{tabular}




\section{Batch leaching test}

\section{C\&D Waste: Crushed concrete \& tiles}

\section{Leached amount}

L/S= $2 \mathrm{l} / \mathrm{kg}$

\begin{tabular}{|c|c|c|c|c|c|c|c|c|}
\hline EluateParameter & $\begin{array}{c}\text { No of } \\
\text { Samples }\end{array}$ & $\begin{array}{c}\text { Avg } \\
(\mathrm{mg} / \mathrm{kg})\end{array}$ & $\begin{array}{c}\text { Min } \\
(\mathrm{mg} / \mathrm{kg})\end{array}$ & $\begin{array}{c}\text { Max } \\
(\mathrm{mg} / \mathrm{kg})\end{array}$ & $\begin{array}{l}\text { Median } \\
(\mathrm{mg} / \mathrm{kg})\end{array}$ & $\begin{array}{c}\text { EU WAC } \\
\text { Inert }\end{array}$ & $\begin{array}{l}\text { EU WAC } \\
\text { non-haz }\end{array}$ & $\begin{array}{c}\text { EU WAC } \\
\text { haz }\end{array}$ \\
\hline As & 2 & 0.0046 & 0.0042 & 0.005 & 0.0046 & 0.1 & 0.4 & 6 \\
\hline $\mathrm{Ba}$ & 2 & 0.073 & 0.046 & 0.1 & 0.073 & 7 & 30 & 100 \\
\hline $\mathrm{Cd}$ & 2 & 0.0004 & 0.0004 & 0.0004 & 0.00040 & 0.03 & 0.6 & 3 \\
\hline Chloride & 2 & 160 & 120 & 190 & 160 & 550 & 10000 & 17000 \\
\hline $\mathrm{Cr}$ & 2 & 0.12 & 0.11 & 0.12 & 0.12 & 0.2 & 4 & 25 \\
\hline $\mathrm{Cu}$ & 2 & 0.14 & 0.13 & 0.14 & 0.14 & 0.9 & 25 & 50 \\
\hline $\mathrm{Hg}$ & 2 & 0.000045 & 0.000037 & 0.000054 & 0.000045 & 0.003 & 0.05 & 0.5 \\
\hline$\overline{\mathrm{Ni}}$ & 2 & 0.041 & 0.024 & 0.058 & 0.041 & 0.2 & 5 & 20 \\
\hline $\mathrm{Pb}$ & 2 & 0.002 & 0.002 & 0.002 & 0.0020 & 0.2 & 5 & 25 \\
\hline Sulphate & 2 & 340 & 200 & 480 & 340 & 560 & 10000 & 25000 \\
\hline $\mathrm{Zn}$ & 2 & 0.02 & 0.02 & 0.02 & 0.020 & 2 & 25 & 90 \\
\hline
\end{tabular}

\begin{tabular}{|c|c|c|c|c|c|c|c|c|}
\hline EluateParameter & $\begin{array}{c}\text { No of } \\
\text { Samples }\end{array}$ & $\begin{array}{c}\text { Avg } \\
(\mathrm{mg} / \mathrm{kg})\end{array}$ & $\begin{array}{c}\text { Min } \\
(\mathrm{mg} / \mathrm{kg})\end{array}$ & $\begin{array}{c}\text { Max } \\
(\mathrm{mg} / \mathrm{kg})\end{array}$ & $\begin{array}{l}\text { Median } \\
(\mathrm{mg} / \mathrm{kg})\end{array}$ & $\begin{array}{c}\text { EU WAC } \\
\text { Inert }\end{array}$ & $\begin{array}{l}\text { EU WAC } \\
\text { non-haz }\end{array}$ & $\begin{array}{c}\text { EU WAC } \\
\text { haz }\end{array}$ \\
\hline As & 2 & 0.0046 & 0.0042 & 0.005 & $\mid 0.0046$ & 0.1 & 0.4 & 6 \\
\hline $\mathrm{Ba}$ & 2 & 0.073 & 0.046 & 0.1 & 0.073 & 7 & 30 & 100 \\
\hline $\mathrm{Cd}$ & 1 & 0.0004 & 0.0004 & 0.0004 & 0.00040 & 0.03 & 0.6 & 3 \\
\hline Chloride & 2 & 160 & 120 & 190 & 160 & 550 & 10000 & 17000 \\
\hline $\mathrm{Cr}$ & 2 & 0.12 & 0.11 & 0.12 & 0.12 & 0.2 & 4 & 25 \\
\hline $\mathrm{Cu}$ & 2 & 0.14 & 0.13 & 0.14 & 0.14 & 0.9 & 25 & 50 \\
\hline $\mathrm{Hg}$ & 2 & 0.000045 & 0.000037 & 0.000054 & 0.000045 & 0.003 & 0.05 & 0.5 \\
\hline $\mathrm{Ni}$ & 2 & 0.041 & 0.024 & 0.058 & 0.041 & 0.2 & 5 & 20 \\
\hline Sulphate & 2 & 340 & 200 & 480 & 340 & 560 & 10000 & 25000 \\
\hline
\end{tabular}

Statistics for Parameter value (for upper table)
\begin{tabular}{|l|c|c|c|}
\hline Parameter & $\begin{array}{c}\text { No of } \\
\text { Samples }\end{array}$ & Min & Max \\
\hline $\mathrm{pH}$ & 2 & 12 & 12 \\
\hline
\end{tabular}




\section{Batch leaching test}

\section{C\&D Waste: Crushed tiles}

\section{Leached amount} $\mathrm{L} / \mathrm{S}=\mathbf{2} \mathrm{l} / \mathrm{kg}$

Statistics INCLUDING measurements below detection limit (=detection limit)

\begin{tabular}{|c|c|c|c|c|c|c|c|c|}
\hline EluateParameter & $\begin{array}{c}\text { No of } \\
\text { Samples }\end{array}$ & $\begin{array}{c}\text { Avg } \\
(\mathrm{mg} / \mathrm{kg})\end{array}$ & $\begin{array}{c}\text { Min } \\
(\mathrm{mg} / \mathrm{kg})\end{array}$ & $\begin{array}{c}\text { Max } \\
(\mathrm{mg} / \mathrm{kg})\end{array}$ & $\begin{array}{l}\text { Median } \\
(\mathrm{mg} / \mathrm{kg})\end{array}$ & $\begin{array}{c}\text { EU WAC } \\
\text { Inert }\end{array}$ & $\begin{array}{l}\text { EU WAC } \\
\text { non-haz }\end{array}$ & $\begin{array}{c}\text { EU WAC } \\
\text { haz }\end{array}$ \\
\hline As & 1 & 0.0028 & 0.0028 & 0.0028 & 0.0028 & 0.1 & 0.4 & 6 \\
\hline $\mathrm{Ba}$ & 1 & 0.044 & 0.044 & 0.044 & 0.044 & 7 & 30 & 100 \\
\hline $\mathrm{Cd}$ & 1 & 0.0004 & 0.0004 & 0.0004 & 0.00040 & 0.03 & 0.6 & 3 \\
\hline \begin{tabular}{|l} 
Chloride \\
\end{tabular} & 1 & 120 & 120 & 120 & 120 & 550 & 10000 & 17000 \\
\hline $\mathrm{Cr}$ & 1 & 0.18 & 0.18 & 0.18 & 0.18 & 0.2 & 4 & 25 \\
\hline $\mathrm{Cu}$ & 1 & 0.05 & 0.05 & 0.05 & 0.050 & 0.9 & 25 & 50 \\
\hline $\mathrm{Hg}$ & 1 & 0.000019 & 0.000019 & 0.000019 & 0.000019 & 0.003 & 0.05 & 0.5 \\
\hline $\mathrm{Ni}$ & 1 & 0.015 & 0.015 & 0.015 & 0.015 & 0.2 & 5 & 20 \\
\hline $\mathrm{Pb}$ & 1 & 0.002 & 0.002 & 0.002 & 0.0020 & 0.2 & 5 & 25 \\
\hline \begin{tabular}{|l|} 
Sulphate \\
\end{tabular} & 1 & 1000 & 1000 & 1000 & 1000 & 560 & 10000 & 25000 \\
\hline $\mathrm{Zn}$ & 1 & 0.02 & 0.02 & 0.02 & 0.020 & 2 & 25 & 90 \\
\hline
\end{tabular}

\begin{tabular}{|c|c|c|c|c|c|c|c|c|}
\hline EluateParameter & $\begin{array}{c}\text { No of } \\
\text { Samples }\end{array}$ & $\begin{array}{c}\text { Avg } \\
(\mathrm{mg} / \mathrm{kg})\end{array}$ & $\begin{array}{c}\text { Min } \\
(\mathrm{mg} / \mathrm{kg})\end{array}$ & $\begin{array}{c}\text { Max } \\
(\mathrm{mg} / \mathrm{kg})\end{array}$ & $\begin{array}{l}\text { Median } \\
(\mathrm{mg} / \mathrm{kg})\end{array}$ & $\begin{array}{c}\text { EU WAC } \\
\text { Inert }\end{array}$ & $\begin{array}{l}\text { EU WAC } \\
\text { non-haz }\end{array}$ & $\begin{array}{c}\text { EU WAC } \\
\text { haz }\end{array}$ \\
\hline As & 1 & 0.0028 & 0.0028 & 0.0028 & 0.0028 & 0.1 & 0.4 & 6 \\
\hline $\mathrm{Ba}$ & 1 & 0.044 & 0.044 & 0.044 & 0.044 & 7 & 30 & 100 \\
\hline Chloride & 1 & 120 & 120 & 120 & 120 & 550 & 10000 & 17000 \\
\hline $\mathrm{Cr}$ & 1 & 0.18 & 0.18 & 0.18 & 0.18 & 0.2 & 4 & 25 \\
\hline $\mathrm{Cu}$ & 1 & 0.05 & 0.05 & 0.05 & 0.050 & 0.9 & 25 & 50 \\
\hline $\mathrm{Hg}$ & 1 & 0.000019 & 0.000019 & 0.000019 & 0.000019 & 0.003 & 0.05 & 0.5 \\
\hline $\mathrm{Ni}$ & 1 & 0.015 & 0.015 & 0.015 & 0.015 & 0.2 & 5 & 20 \\
\hline Sulphate & 1 & 1000 & 1000 & 1000 & 1000 & 560 & 10000 & 25000 \\
\hline
\end{tabular}

Statistics for Parameter value (for upper table)
\begin{tabular}{|l|c|c|c|}
\hline Parameter & $\begin{array}{c}\text { No of } \\
\text { Samples }\end{array}$ & Min & Max \\
\hline $\mathrm{pH}$ & 1 & 11 & 11 \\
\hline
\end{tabular}




\section{Batch leaching test}

\section{C\&D Waste: Gypsum-based materials}

Leached amount

L/S= $2 \mathrm{l} / \mathrm{kg}$

Statistics INCLUDING measurements below detection limit (=detection limit)

\begin{tabular}{|c|c|c|c|c|c|c|c|c|}
\hline EluateParameter & $\begin{array}{c}\text { No of } \\
\text { Samples }\end{array}$ & $\begin{array}{c}\text { Avg } \\
(\mathrm{mg} / \mathrm{kg})\end{array}$ & $\begin{array}{c}\text { Min } \\
(\mathrm{mg} / \mathrm{kg})\end{array}$ & $\begin{array}{c}\text { Max } \\
(\mathrm{mg} / \mathrm{kg})\end{array}$ & $\begin{array}{l}\text { Median } \\
\text { (mg/kg) }\end{array}$ & $\begin{array}{c}\text { EU WAC } \\
\text { Inert }\end{array}$ & $\begin{array}{l}\text { EU WAC } \\
\text { non-haz }\end{array}$ & $\begin{array}{c}\text { EU WAC } \\
\text { haz }\end{array}$ \\
\hline As & 1 & 0.01 & 0.01 & 0.01 & 0.010 & 0.1 & 0.4 & 6 \\
\hline $\mathrm{Cd}$ & 1 & 0.02 & 0.02 & 0.02 & 0.020 & 0.03 & 0.6 & 3 \\
\hline \begin{tabular}{|l} 
Chloride \\
\end{tabular} & 1 & 90 & 90 & 90 & 90 & 550 & 10000 & 17000 \\
\hline $\mathrm{Cr}$ & 1 & 0.0006 & 0.0006 & 0.0006 & 0.00060 & 0.2 & 4 & 25 \\
\hline $\mathrm{Cu}$ & 1 & 0.1 & 0.1 & 0.1 & 0.10 & 0.9 & 25 & 50 \\
\hline DOC & 1 & 640 & 640 & 640 & 640 & 240 & 380 & 480 \\
\hline \begin{tabular}{|l|}
$\mathrm{Ni}$ \\
\end{tabular} & 1 & 0.12 & 0.12 & 0.12 & 0.12 & 0.2 & 5 & 20 \\
\hline $\mathrm{Pb}$ & 1 & 0.002 & 0.002 & 0.002 & 0.0020 & 0.2 & 5 & 25 \\
\hline Sulphate & 1 & 3200 & 3200 & 3200 & 3200 & 560 & 10000 & 25000 \\
\hline$\overline{Z n}$ & 1 & 0.15 & 0.15 & 0.15 & 0.15 & 2 & 25 & 90 \\
\hline
\end{tabular}

Statistics EXCLUDING measurements below detection limit

\begin{tabular}{|c|c|c|c|c|c|c|c|c|}
\hline EluateParameter & No of & Avg & Min & Max & Median & EU WAC & EU WAC & EU WAC \\
\hline As & 1 & 0.01 & 0.01 & 0.01 & 0.010 & 0.1 & 0.4 & 6 \\
\hline $\mathrm{Cd}$ & 1 & 0.02 & 0.02 & 0.02 & 0.020 & 0.03 & 0.6 & 3 \\
\hline Chloride & 1 & 90 & 90 & 90 & 90 & 550 & 10000 & 17000 \\
\hline $\mathrm{Cu}$ & 1 & 0.1 & 0.1 & 0.1 & 0.10 & 0.9 & 25 & 50 \\
\hline $\mathrm{DOC}$ & 1 & 640 & 640 & 640 & 640 & 240 & 380 & 480 \\
\hline \begin{tabular}{|l|}
$\mathrm{Ni}$ \\
\end{tabular} & 1 & 0.12 & 0.12 & 0.12 & 0.12 & 0.2 & 5 & 20 \\
\hline Sulphate & 1 & 3200 & 3200 & 3200 & 3200 & 560 & 10000 & 25000 \\
\hline $\mathrm{Zn}$ & 1 & 0.15 & 0.15 & 0.15 & 0.15 & 2 & 25 & 90 \\
\hline
\end{tabular}

Statistics for Parameter value (for upper table)
\begin{tabular}{|l|c|r|r|}
\hline Parameter & $\begin{array}{c}\text { No of } \\
\text { Samples }\end{array}$ & Min & Max \\
\hline pH & 1 & 7.8 & 7.8 \\
\hline
\end{tabular}




\section{Batch leaching test}

\section{Glass}

Leached amount

L/S= 2 I/kg

\begin{tabular}{|c|c|c|c|c|c|c|c|c|}
\hline EluateParameter & $\begin{array}{c}\text { No of } \\
\text { Samples }\end{array}$ & $\begin{array}{c}\text { Avg } \\
(\mathrm{mg} / \mathrm{kg})\end{array}$ & $\begin{array}{c}\text { Min } \\
(\mathrm{mg} / \mathrm{kg})\end{array}$ & $\begin{array}{c}\text { Max } \\
(\mathrm{mg} / \mathrm{kg})\end{array}$ & $\begin{array}{l}\text { Median } \\
\text { (mg/kg) }\end{array}$ & $\begin{array}{c}\text { EU WAC } \\
\text { Inert }\end{array}$ & $\begin{array}{l}\text { EU WAC } \\
\text { non-haz }\end{array}$ & $\begin{array}{c}\text { EU WAC } \\
\text { haz }\end{array}$ \\
\hline As & 1 & 0.0046 & 0.0046 & 0.0046 & 0.0046 & 0.1 & 0.4 & 6 \\
\hline $\mathrm{Cd}$ & 1 & 0.0002 & \begin{tabular}{l|l}
0.0002 \\
\end{tabular} & 0.0002 & 0.00020 & 0.03 & 0.6 & 3 \\
\hline Chloride & 1 & 6.8 & 6.8 & 6.8 & 6.8 & 550 & 10000 & 17000 \\
\hline $\mathrm{Cr}$ & 1 & 0.0032 & 0.0032 & 0.0032 & $\begin{array}{ll}0.0032 \\
\end{array}$ & 0.2 & 4 & 25 \\
\hline $\mathrm{Cu}$ & 1 & 0.012 & 0.012 & 0.012 & 0.012 & 0.9 & 25 & 50 \\
\hline DOC & 1 & 11 & 11 & 11 & 11 & 240 & 380 & 480 \\
\hline $\mathrm{Ni}$ & 1 & 0.0036 & $\begin{array}{ll}0.0036 \\
\end{array}$ & 0.0036 & 0.0036 & 0.2 & 5 & 20 \\
\hline $\mathrm{Pb}$ & 1 & 0.084 & 0.084 & 0.084 & 0.084 & 0.2 & 5 & 25 \\
\hline Sulphate & 1 & 28 & 28 & 28 & 28 & 560 & 10000 & 25000 \\
\hline $\mathrm{Zn}$ & 1 & 0.022 & 0.022 & 0.022 & 0.022 & 2 & 25 & 90 \\
\hline
\end{tabular}

\begin{tabular}{|c|c|c|c|c|c|c|c|c|}
\hline EluateParameter & No of & Avg & Min & $\operatorname{Max}$ & Median & \begin{tabular}{|l} 
EU WAC \\
\end{tabular} & EU WAC & EU WAC \\
\hline As & 1 & 0.0046 & 0.0046 & 0.0046 & 0.0046 & 0.1 & 0.4 & 6 \\
\hline $\mathrm{Cd}$ & 1 & 0.0002 & 0.0002 & 0.0002 & 0.00020 & 0.03 & 0.6 & 3 \\
\hline \begin{tabular}{|l} 
Chloride \\
\end{tabular} & 1 & 6.8 & 6.8 & 6.8 & 6.8 & 550 & 10000 & 17000 \\
\hline $\mathrm{Cr}$ & 1 & 0.0032 & 0.0032 & 0.0032 & 0.0032 & 0.2 & 4 & 25 \\
\hline $\mathrm{Cu}$ & 1 & 0.012 & 0.012 & 0.012 & 0.012 & 0.9 & 25 & 50 \\
\hline $\mathrm{DOC}$ & 1 & 11 & 11 & 11 & 11 & 240 & 380 & 480 \\
\hline $\mathrm{Ni}$ & 1 & 0.0036 & 0.0036 & 0.0036 & 0.0036 & 0.2 & 5 & 20 \\
\hline $\mathrm{Pb}$ & 1 & 0.084 & 0.084 & 0.084 & 0.084 & 0.2 & 5 & 25 \\
\hline Sulphate & 1 & 28 & 28 & 28 & 28 & 560 & 10000 & 25000 \\
\hline $\mathrm{Zn}$ & 1 & 0.022 & 0.022 & 0.022 & 0.022 & 2 & 25 & 90 \\
\hline
\end{tabular}

Statistics for Parameter value (for upper table)
\begin{tabular}{|l|c|c|c|}
\hline Parameter & $\begin{array}{c}\text { No of } \\
\text { Samples }\end{array}$ & Min & Max \\
\hline $\mathrm{pH}$ & 1 & 11 & 11 \\
\hline
\end{tabular}




\section{Batch leaching test}

\section{Mixed inert container waste}

\section{Leached amount}

L/S= 2 I/kg

\begin{tabular}{|c|c|c|c|c|c|c|c|c|}
\hline EluateParameter & $\begin{array}{c}\text { No of } \\
\text { Samples }\end{array}$ & $\begin{array}{c}\text { Avg } \\
(\mathrm{mg} / \mathrm{kg})\end{array}$ & $\begin{array}{c}\text { Min } \\
(\mathrm{mg} / \mathrm{kg})\end{array}$ & $\begin{array}{c}\text { Max } \\
(\mathrm{mg} / \mathrm{kg})\end{array}$ & $\begin{array}{l}\text { Median } \\
(\mathrm{mg} / \mathrm{kg})\end{array}$ & $\begin{array}{c}\text { EU WAC } \\
\text { Inert }\end{array}$ & $\begin{array}{l}\text { EU WAC } \\
\text { non-haz }\end{array}$ & $\begin{array}{c}\text { EU WAC } \\
\text { haz }\end{array}$ \\
\hline As & 3 & 0.002 & 0.002 & 0.002 & 0.0020 & 0.1 & 0.4 & 6 \\
\hline $\mathrm{Cd}$ & 3 & 0.0006 & 0.0006 & 0.0006 & 0.00060 & 0.03 & 0.6 & 3 \\
\hline Chloride & 3 & 85 & 84 & 86 & 86 & 550 & 10000 & 17000 \\
\hline $\mathrm{Cr}$ & 3 & 0.27 & 0.24 & 0.32 & 0.24 & 0.2 & 4 & 25 \\
\hline $\mathrm{Cu}$ & 3 & 0.12 & 0.11 & 0.13 & 0.11 & 0.9 & 25 & 50 \\
\hline DOC & 3 & 120 & 120 & 130 & 120 & 240 & 380 & 480 \\
\hline $\mathrm{Ni}$ & 3 & 0.2 & 0.2 & 0.2 & 0.20 & 0.2 & 5 & 20 \\
\hline $\mathrm{Pb}$ & 3 & 0.062 & 0.032 & 0.12 & 0.034 & 0.2 & 5 & 25 \\
\hline Sulphate & 3 & 2600 & 2600 & 2600 & 2600 & 560 & 10000 & 25000 \\
\hline \begin{tabular}{|l|l}
$\mathrm{Zn}$ \\
\end{tabular} & 3 & 0.023 & 0.01 & 0.034 & 0.024 & 2 & 25 & 90 \\
\hline
\end{tabular}

\begin{tabular}{|c|c|c|c|c|c|c|c|c|}
\hline EluateParameter & $\begin{array}{c}\text { No of } \\
\text { Samples }\end{array}$ & $\begin{array}{c}\text { Avg } \\
(\mathrm{mg} / \mathrm{kg})\end{array}$ & $\begin{array}{c}\text { Min } \\
(\mathrm{mg} / \mathrm{kg})\end{array}$ & $\begin{array}{c}\text { Max } \\
(\mathrm{mg} / \mathrm{kg})\end{array}$ & $\begin{array}{l}\text { Median } \\
(\mathrm{mg} / \mathrm{kg})\end{array}$ & $\begin{array}{c}\text { EU WAC } \\
\text { Inert }\end{array}$ & $\begin{array}{l}\text { EU WAC } \\
\text { non-haz }\end{array}$ & $\begin{array}{c}\text { EU WAC } \\
\text { haz }\end{array}$ \\
\hline Chloride & 3 & 85 & 84 & 86 & 86 & 550 & 10000 & 17000 \\
\hline $\mathrm{Cr}$ & 3 & 0.27 & 0.24 & 0.32 & 0.24 & 0.2 & 4 & 25 \\
\hline $\mathrm{Cu}$ & 3 & 0.12 & 0.11 & 0.13 & 0.11 & 0.9 & 25 & 50 \\
\hline$\overline{\mathrm{DOC}}$ & 2 & 120 & 120 & 120 & 120 & 240 & 380 & 480 \\
\hline $\mathrm{Pb}$ & 3 & 0.062 & 0.032 & 0.12 & 0.034 & 0.2 & 5 & 25 \\
\hline Sulphate & 3 & 2600 & 2600 & 2600 & 2600 & 560 & 10000 & 25000 \\
\hline$\overline{Z n}$ & 2 & 0.029 & 0.024 & 0.034 & 0.029 & 2 & 25 & 90 \\
\hline
\end{tabular}

Statistics for Parameter value (for upper table)
\begin{tabular}{|l|c|c|c|}
\hline Parameter & $\begin{array}{c}\text { No of } \\
\text { Samples }\end{array}$ & Min & Max \\
\hline $\mathrm{pH}$ & 3 & 12 & 12 \\
\hline
\end{tabular}




\section{Batch leaching test}

\section{MSWI APC semidry product}

Leached amount

L/S $=10 \mathrm{I} / \mathrm{kg}$

\begin{tabular}{|c|c|c|c|c|c|c|c|c|}
\hline EluateParameter & $\begin{array}{c}\text { No of } \\
\text { Samples }\end{array}$ & $\begin{array}{c}\text { Avg } \\
(\mathrm{mg} / \mathrm{kg})\end{array}$ & $\begin{array}{c}\text { Min } \\
(\mathrm{mg} / \mathrm{kg})\end{array}$ & $\begin{array}{c}\text { Max } \\
(\mathrm{mg} / \mathrm{kg})\end{array}$ & $\begin{array}{l}\text { Median } \\
(\mathrm{mg} / \mathrm{kg})\end{array}$ & $\begin{array}{c}\text { EU WAC } \\
\text { Inert }\end{array}$ & $\begin{array}{l}\text { EU WAC } \\
\text { non-haz }\end{array}$ & $\begin{array}{c}\text { EU WAC } \\
\text { haz }\end{array}$ \\
\hline As & 4 & 0.05 & 0.012 & 0.088 & 0.050 & 0.5 & 2 & 25 \\
\hline $\mathrm{Ba}$ & 4 & 2 & 0.66 & 3.4 & 1.9 & 20 & 100 & 300 \\
\hline $\mathrm{Cd}$ & 4 & 0.0043 & 0.0023 & 0.005 & 0.0050 & 0.04 & 1 & 5 \\
\hline Chloride & 4 & 110000 & 92000 & 130000 & 120000 & 800 & 15000 & 25000 \\
\hline $\mathrm{Cr}$ & 4 & 1.7 & 0.088 & 3.9 & 1.5 & 0.5 & 10 & 70 \\
\hline $\mathrm{Cu}$ & 4 & 3.9 & 1.5 & 6.4 & 3.9 & 2 & 50 & 100 \\
\hline Fluoride & 4 & 150 & 40 & 440 & 50 & 10 & 150 & 500 \\
\hline $\mathrm{Hg}$ & 4 & 0.04 & 0.0092 & 0.093 & 0.028 & 0.01 & 0.2 & 2 \\
\hline Mo & 4 & 2.4 & 1.8 & 2.8 & 2.4 & 0.5 & 10 & 30 \\
\hline $\mathrm{Ni}$ & 4 & 0.2 & 0.05 & 0.36 & 0.19 & 0.4 & 10 & 40 \\
\hline $\mathrm{Pb}$ & 4 & 660 & 520 & 840 & 630 & 0.5 & 10 & 50 \\
\hline$\overline{S b}$ & 4 & 0.0097 & 0.0086 & 0.01 & 0.010 & 0.06 & 0.7 & 5 \\
\hline $\mathrm{Se}$ & 4 & 0.18 & 0.14 & 0.22 & 0.18 & 0.1 & 0.5 & \\
\hline Sulphate & 4 & 14000 & 1700 & 20000 & 17000 & 1000 & 20000 & 50000 \\
\hline $\mathrm{Zn}$ & 4 & 54 & 46 & 62 & 55 & 4 & 50 & 200 \\
\hline
\end{tabular}

Statistics EXCLUDING measurements below detection limit

\begin{tabular}{|c|c|c|c|c|c|c|c|c|}
\hline EluateParameter & $\begin{array}{c}\text { No of } \\
\text { Samples }\end{array}$ & $\begin{array}{c}\text { Avg } \\
(\mathrm{mg} / \mathrm{kg})\end{array}$ & $\begin{array}{c}\text { Min } \\
(\mathrm{mg} / \mathrm{kg})\end{array}$ & $\begin{array}{c}\text { Max } \\
(\mathrm{mg} / \mathrm{kg})\end{array}$ & $\begin{array}{l}\text { Median } \\
(\mathrm{mg} / \mathrm{kg})\end{array}$ & $\begin{array}{c}\text { EU WAC } \\
\text { Inert }\end{array}$ & $\begin{array}{l}\text { EU WAC } \\
\text { non-haz }\end{array}$ & $\begin{array}{c}\text { EU WAC } \\
\text { haz }\end{array}$ \\
\hline As & 4 & 0.05 & 0.012 & 0.088 & 0.050 & 0.5 & 2 & 25 \\
\hline $\mathrm{Ba}$ & 4 & 2 & 0.66 & 3.4 & 1.9 & 20 & 100 & 300 \\
\hline $\mathrm{Cd}$ & 1 & 0.0023 & 年.0023 & $\begin{array}{ll}0.0023 \\
\end{array}$ & 0.0023 & 0.04 & 1 & 5 \\
\hline Chloride & 4 & 110000 & 92000 & 130000 & 120000 & 800 & 15000 & 25000 \\
\hline $\mathrm{Cr}$ & 4 & 1.7 & 0.088 & 3.9 & 1.5 & 0.5 & 10 & 70 \\
\hline $\mathrm{Cu}$ & 4 & 3.9 & 1.5 & 6.4 & 3.9 & 2 & 50 & 100 \\
\hline Fluoride & 4 & 150 & 40 & 440 & 50 & 10 & 150 & 500 \\
\hline $\mathrm{Hg}$ & 4 & 0.04 & 0.0092 & 0.093 & 0.028 & 0.01 & 0.2 & 2 \\
\hline Mo & 4 & 2.4 & 1.8 & 2.8 & 2.4 & 0.5 & 10 & 30 \\
\hline $\mathrm{Ni}$ & 3 & 0.25 & 0.15 & 0.36 & 0.23 & 0.4 & 10 & 40 \\
\hline $\mathrm{Pb}$ & 4 & 660 & 520 & 840 & 630 & 0.5 & 10 & 50 \\
\hline $\mathrm{Sb}$ & 1 & 0.0086 & 0.0086 & 0.0086 & 0.0086 & 0.06 & 0.7 & 5 \\
\hline $\mathrm{Se}$ & 4 & 0.18 & 0.14 & 0.22 & 0.18 & 0.1 & 0.5 & \\
\hline Sulphate & 4 & 14000 & 1700 & 20000 & 17000 & 1000 & 20000 & 50000 \\
\hline $\mathrm{Zn}$ & 4 & 54 & 46 & 62 & 55 & 4 & 50 & 200 \\
\hline
\end{tabular}

Statistics for Parameter value (for upper table)

\begin{tabular}{|l|c|c|c|}
\hline Parameter & $\begin{array}{c}\text { No of } \\
\text { Samples }\end{array}$ & Min & Max \\
\hline $\mathrm{pH}$ & 4 & 12 & 12 \\
\hline
\end{tabular}




\section{Batch leaching test}

\section{MSWI BA}

Leached amount L/S= $2 \mathrm{l} / \mathrm{kg}$

\begin{tabular}{|c|c|c|c|c|c|c|c|c|}
\hline EluateParameter & $\begin{array}{c}\text { No of } \\
\text { Samples }\end{array}$ & $\begin{array}{c}\text { Avg } \\
(\mathrm{mg} / \mathrm{kg})\end{array}$ & $\begin{array}{c}\text { Min } \\
(\mathrm{mg} / \mathrm{kg})\end{array}$ & $\begin{array}{c}\text { Max } \\
(\mathrm{mg} / \mathrm{kg})\end{array}$ & $\begin{array}{l}\text { Median } \\
(\mathrm{mg} / \mathrm{kg})\end{array}$ & $\begin{array}{c}\text { EU WAC } \\
\text { Inert }\end{array}$ & $\begin{array}{l}\text { EU WAC } \\
\text { non-haz }\end{array}$ & $\begin{array}{c}\text { EU WAC } \\
\text { haz }\end{array}$ \\
\hline As & 70 & 0.0031 & 0.0002 & 0.0088 & 0.0026 & 0.1 & 0.4 & \\
\hline $\mathrm{Ba}$ & 14 & 0.079 & 0.047 & 0.12 & 0.074 & 7 & 30 & 100 \\
\hline $\mathrm{Cd}$ & 70 & 0.00074 & 0.0001 & 0.014 & 0.00040 & 0.03 & 0.6 & - \\
\hline Chloride & 70 & 1100 & 500 & 1900 & 950 & 550 & 10000 & 17000 \\
\hline $\mathrm{Cr}$ & 70 & 0.029 & 0.0042 & 0.24 & 0.019 & 0.2 & 4 & 25 \\
\hline $\mathrm{Cu}$ & $\overline{70}$ & 1.5 & 0.099 & 9.6 & 0.98 & 0.9 & 25 & 50 \\
\hline $\mathrm{DOC}$ & 65 & 150 & 1 & 490 & 140 & 240 & 380 & 480 \\
\hline Fluoride & 6 & 11 & 1.5 & 30 & 10 & 4 & 60 & 200 \\
\hline $\mathrm{Hg}$ & 7 & 0.000067 & 0.00004 & 0.00021 & 0.000040 & 0.003 & 0.05 & 0.5 \\
\hline Mo & 17 & 0.52 & 0.19 & 0.93 & 0.56 & 0.3 & 5 & 20 \\
\hline $\mathrm{Ni}$ & 70 & 0.013 & 0.001 & 0.11 & 0.0087 & 0.2 & 5 & 20 \\
\hline $\mathrm{Pb}$ & 70 & 0.0043 & 0.00064 & 0.037 & 0.0028 & 0.2 & 5 & 25 \\
\hline $\mathrm{Sb}$ & 6 & 0.07 & 0.056 & 0.083 & 0.070 & 0.02 & 0.2 & 2 \\
\hline $\mathrm{Se}$ & 6 & 0.008 & 0.007 & 0.0097 & 0.0081 & 0.06 & 0.3 & 4 \\
\hline Sulphate & 70 & 1500 & 450 & 2800 & 1500 & 560 & 10000 & 25000 \\
\hline TDS & 5 & 5800 & 5200 & 6800 & 5600 & 4000 & 40000 & 70000 \\
\hline $\mathrm{Zn}$ & 70 & 0.016 & 0.00048 & 0.11 & 0.010 & 2 & 25 & 90 \\
\hline
\end{tabular}

\begin{tabular}{|c|c|c|c|c|c|c|c|c|}
\hline EluateParameter & \begin{tabular}{|c|} 
No of \\
Samples
\end{tabular} & $\begin{array}{c}\text { Avg } \\
\text { (mg/kg) }\end{array}$ & $\begin{array}{c}\text { Min } \\
(\mathrm{mg} / \mathrm{kg})\end{array}$ & $\begin{array}{c}\text { Max } \\
(\mathrm{mg} / \mathrm{kg})\end{array}$ & $\begin{array}{l}\text { Median } \\
(\mathrm{mg} / \mathrm{kg})\end{array}$ & $\begin{array}{c}\text { EU WAC } \\
\text { Inert }\end{array}$ & $\begin{array}{c}\text { EU WAC } \\
\text { non-haz }\end{array}$ & $\begin{array}{c}\text { EU WAC } \\
\text { haz }\end{array}$ \\
\hline As & 60 & 0.0033 & 0.0002 & 0.0088 & 0.0028 & 0.1 & 0.4 & 6 \\
\hline $\mathrm{Ba}$ & 14 & 0.079 & 0.047 & 0.12 & 0.074 & 7 & 30 & 100 \\
\hline $\mathrm{Cd}$ & 41 & 0.00064 & 0.00014 & 0.0026 & 0.00048 & 0.03 & 0.6 & 3 \\
\hline Chloride & 70 & 1100 & 500 & 1900 & 950 & 550 & 10000 & 17000 \\
\hline $\mathrm{Cr}$ & 70 & 0.029 & 0.0042 & 0.24 & 0.019 & 0.2 & 4 & 25 \\
\hline $\mathrm{Cu}$ & 70 & 1.5 & 0.099 & 9.6 & 0.98 & 0.9 & 25 & 50 \\
\hline DOC & 65 & 150 & 1 & 490 & 140 & 240 & 380 & 480 \\
\hline Fluoride & 3 & 11 & 10 & 12 & 10 & 4 & 60 & 200 \\
\hline $\mathrm{Hg}$ & 3 & 0.0001 & 0.000045 & 0.00021 & 0.000053 & 0.003 & 0.05 & 0.5 \\
\hline Mo & 17 & 0.52 & 0.19 & 0.93 & 0.56 & 0.3 & 5 & 20 \\
\hline $\mathrm{Ni}$ & 67 & 0.014 & 0.0014 & 0.11 & 0.0091 & 0.2 & 5 & 20 \\
\hline $\mathrm{Pb}$ & 70 & 0.0043 & 0.00064 & 0.037 & 0.0028 & 0.2 & 5 & 25 \\
\hline $\mathrm{Sb}$ & 6 & 0.07 & 0.056 & 0.083 & 0.070 & 0.02 & 0.2 & 2 \\
\hline $\mathrm{Se}$ & 6 & 0.008 & 0.007 & 0.0097 & 0.0081 & 0.06 & 0.3 & 4 \\
\hline \begin{tabular}{|l} 
Sulphate \\
\end{tabular} & 70 & 1500 & 450 & 2800 & 1500 & 560 & 10000 & 25000 \\
\hline TDS & 5 & 5800 & 5200 & 6800 & 5600 & 4000 & 40000 & 70000 \\
\hline $\mathrm{Zn}$ & 64 & 0.017 & 0.00048 & 0.11 & 0.011 & 2 & 25 & 90 \\
\hline
\end{tabular}

Statistics for Parameter value (for upper table)

\begin{tabular}{|l|c|c|c|}
\hline Parameter & $\begin{array}{c}\text { No of } \\
\text { Samples }\end{array}$ & Min & Max \\
\hline $\mathrm{pH}$ & 70 & & 9 \\
\hline
\end{tabular}




\section{Batch leaching test}

\section{MSWI FA}

Leached amount

$\mathrm{L} / \mathrm{S}=10 \mathrm{l} / \mathrm{kg}$

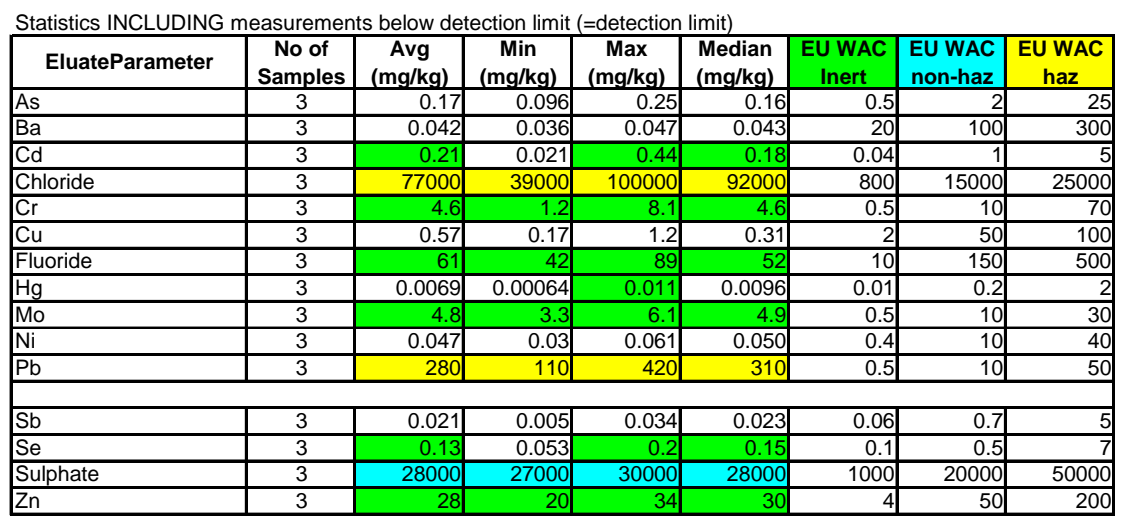

\begin{tabular}{|c|c|c|c|c|c|c|c|c|}
\hline EluateParameter & $\begin{array}{c}\text { No of } \\
\text { Samples }\end{array}$ & $\begin{array}{c}\text { Avg } \\
(\mathrm{mg} / \mathrm{kg})\end{array}$ & $\begin{array}{c}\text { Min } \\
(\mathrm{mg} / \mathrm{kg})\end{array}$ & $\begin{array}{c}\operatorname{Max} \\
(\mathrm{mg} / \mathrm{kq})\end{array}$ & $\begin{array}{l}\text { Median } \\
(\mathrm{mg} / \mathrm{kg})\end{array}$ & $\begin{array}{c}\text { EU WAC } \\
\text { Inert }\end{array}$ & $\begin{array}{l}\text { EU WAC } \\
\text { non-haz }\end{array}$ & $\begin{array}{c}\text { EU WAC } \\
\text { haz }\end{array}$ \\
\hline As & 3 & 0.17 & $\frac{3096}{0.096}$ & 0.25 & 0.16 & 0.5 & 2 & 25 \\
\hline $\mathrm{Ba}$ & 3 & 0.042 & 0.036 & 0.047 & 0.043 & 20 & 100 & 300 \\
\hline $\mathrm{Cd}$ & 3 & 0.21 & 0.021 & 0.44 & 0.18 & 0.04 & 1 & 5 \\
\hline Chloride & 3 & 77000 & 39000 & 100000 & 92000 & 800 & 15000 & 25000 \\
\hline $\mathrm{Cr}$ & 3 & 4.6 & 1.2 & 8.1 & 4.6 & 0.5 & 10 & 70 \\
\hline $\mathrm{Cu}$ & 3 & 0.57 & 0.17 & 1.2 & 0.31 & 2 & 50 & 100 \\
\hline Fluoride & 3 & 61 & 42 & 89 & 52 & 10 & 150 & 500 \\
\hline $\mathrm{Hg}$ & 3 & 0.0069 & 0.00064 & 0.011 & 0.0096 & 0.01 & 0.2 & 2 \\
\hline Mo & 3 & 4.8 & 3.3 & 6.1 & 4.9 & 0.5 & 10 & 30 \\
\hline $\mathrm{Ni}$ & 1 & 0.061 & 0.061 & 0.061 & 0.061 & 0.4 & 10 & 40 \\
\hline $\mathrm{Pb}$ & 3 & 280 & 110 & 420 & 310 & 0.5 & 10 & 50 \\
\hline $\mathrm{Sb}$ & 2 & 0.028 & 0.023 & 0.034 & 0.028 & 0.06 & 0.7 & 5 \\
\hline $\mathrm{Se}$ & 3 & 0.13 & 0.053 & 0.2 & 0.15 & 0.1 & 0.5 & 7 \\
\hline Sulphate & 3 & 28000 & 27000 & 30000 & 28000 & 1000 & 20000 & 50000 \\
\hline $\mathrm{Zn}$ & 3 & 28 & 20 & 34 & 30 & & & \\
\hline
\end{tabular}

Statistics for Parameter value (for upper table)

\begin{tabular}{|l|c|c|c|}
\hline Parameter & $\begin{array}{c}\text { No of } \\
\text { Samples }\end{array}$ & \multicolumn{1}{|c|}{ Min } & Max \\
\hline $\mathrm{pH}$ & 3 & 12 & 12 \\
\hline
\end{tabular}




\section{Batch leaching test}

\section{Road sweepings}

Leached amount

L/S= $2 \mathrm{l} / \mathrm{kg}$

\begin{tabular}{|c|c|c|c|c|c|c|c|c|}
\hline EluateParameter & $\begin{array}{c}\text { No of } \\
\text { Samples }\end{array}$ & $\begin{array}{c}\text { Avg } \\
(\mathrm{mg} / \mathrm{kg})\end{array}$ & $\begin{array}{c}\text { Min } \\
(\mathrm{mg} / \mathrm{kg})\end{array}$ & $\begin{array}{c}\text { Max } \\
(\mathrm{mg} / \mathrm{kg}) \\
\end{array}$ & $\begin{array}{l}\text { Median } \\
(\mathrm{mg} / \mathrm{kg})\end{array}$ & $\begin{array}{c}\text { EU WAC } \\
\text { Inert }\end{array}$ & \begin{tabular}{|c|} 
EU WAC \\
non-haz
\end{tabular} & $\begin{array}{c}\text { EU WAC } \\
\text { haz }\end{array}$ \\
\hline As & 14 & 0.0071 & 0.002 & 0.014 & 0.0062 & 0.1 & 0.4 & 0 \\
\hline $\mathrm{Ba}$ & 8 & 0.084 & 0.044 & 0.15 & 0.087 & 7 & 30 & 100 \\
\hline $\mathrm{Cd}$ & 14 & 0.00082 & 0.0004 & 0.0015 & 0.00082 & 0.03 & 0.6 & 4 \\
\hline \begin{tabular}{|l|} 
Chloride \\
\end{tabular} & 14 & 350 & 48 & 1200 & 150 & 550 & 10000 & 17000 \\
\hline $\mathrm{Cr}$ & 14 & 0.0055 & 0.0024 & 0.017 & 0.0048 & 0.2 & 4 & 25 \\
\hline $\mathrm{Cu}$ & 14 & 0.67 & 0.072 & 1.3 & 0.62 & 0.9 & 25 & 50 \\
\hline DOC & 5 & 200 & 120 & 280 & 160 & 240 & 380 & 480 \\
\hline $\mathrm{Hg}$ & 8 & 0.00043 & 0.0002 & 0.0006 & 0.00040 & 0.003 & 0.05 & 0.5 \\
\hline $\mathrm{Ni}$ & 14 & 0.056 & 0.018 & 0.12 & 0.035 & 0.2 & 5 & 20 \\
\hline $\mathrm{Pb}$ & 14 & 0.041 & 0.005 & 0.12 & 0.015 & 0.2 & 5 & 25 \\
\hline Sulphate & 14 & 140 & 38 & 500 & 78 & 560 & 10000 & 25000 \\
\hline $\mathrm{Zn}$ & 14 & 0.33 & 0.046 & 0.74 & 0.32 & 2 & 25 & 90 \\
\hline
\end{tabular}

\begin{tabular}{|c|c|c|c|c|c|c|c|c|}
\hline EluateParameter & $\begin{array}{c}\text { No of } \\
\text { Samples }\end{array}$ & $\begin{array}{c}\text { Avg } \\
(\mathrm{mg} / \mathrm{kg})\end{array}$ & $\begin{array}{c}\text { Min } \\
(\mathrm{mg} / \mathrm{kg})\end{array}$ & $\begin{array}{c}\text { Max } \\
(\mathrm{mg} / \mathrm{kg})\end{array}$ & $\begin{array}{l}\text { Median } \\
(\mathrm{mg} / \mathrm{kg})\end{array}$ & $\begin{array}{c}\begin{array}{c}\text { EU WAC } \\
\text { Inert }\end{array} \\
\end{array}$ & \begin{tabular}{l|} 
EU WAC \\
non-haz
\end{tabular} & $\begin{array}{c}\text { EU WAC } \\
\text { haz }\end{array}$ \\
\hline As & 12 & 0.008 & 0.0052 & 0.014 & 0.0069 & 0.1 & 0.4 & 6 \\
\hline $\mathrm{Ba}$ & 8 & 0.084 & 0.044 & 0.15 & 0.087 & 7 & 30 & 100 \\
\hline $\mathrm{Cd}$ & 14 & 0.00082 & 0.0004 & 0.0015 & 0.00082 & 0.03 & 0.6 & 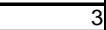 \\
\hline Chloride & 14 & 350 & 48 & 1200 & 150 & 550 & 10000 & 17000 \\
\hline $\mathrm{Cr}$ & 14 & 0.0055 & 0.0024 & 0.017 & 0.0048 & 0.2 & 4 & 25 \\
\hline $\mathrm{Cu}$ & 14 & 0.67 & 0.072 & 1.3 & 0.62 & 0.9 & 25 & 50 \\
\hline$\overline{D O C}$ & 5 & 200 & 120 & 280 & 160 & 240 & 380 & 480 \\
\hline $\mathrm{Hg}$ & 2 & 0.0006 & 0.0006 & 0.0006 & 0.00060 & 0.003 & 0.05 & 0.5 \\
\hline $\mathrm{Ni}$ & 14 & 0.056 & 0.018 & 0.12 & 0.035 & 0.2 & 5 & 20 \\
\hline $\mathrm{Pb}$ & 14 & 0.041 & 0.005 & 0.12 & 0.015 & 0.2 & 5 & 25 \\
\hline Sulphate & 14 & 140 & 38 & 500 & 78 & 560 & 10000 & 25000 \\
\hline$Z n$ & 14 & 0.33 & \begin{tabular}{l|l|}
0.046 \\
\end{tabular} & 0.74 & 0.32 & 2 & 25 & 90 \\
\hline
\end{tabular}

Statistics for Parameter value (for upper table)

\begin{tabular}{|l|c|r|r|}
\hline Parameter & $\begin{array}{c}\text { No of } \\
\text { Samples }\end{array}$ & \multicolumn{1}{|c|}{ Min } & \multicolumn{1}{c|}{ Max } \\
\hline $\mathrm{pH}$ & 14 & 7.4 & 8.2 \\
\hline
\end{tabular}




\section{Batch leaching test}

\section{Uncontaminated Soil}

\section{Leached amount}

$\mathrm{L} / \mathrm{S}=\mathbf{2} \mathrm{I} / \mathrm{kg}$

\begin{tabular}{|c|c|c|c|c|c|c|c|c|}
\hline EluateParameter & $\begin{array}{c}\text { No of } \\
\text { Samples }\end{array}$ & $\begin{array}{c}\text { Avg } \\
(\mathrm{mg} / \mathrm{kg})\end{array}$ & $\begin{array}{c}\text { Min } \\
(\mathrm{mg} / \mathrm{kg})\end{array}$ & $\begin{array}{c}\text { Max } \\
(\mathrm{mg} / \mathrm{kg})\end{array}$ & $\begin{array}{l}\text { Median } \\
(\mathrm{mg} / \mathrm{kg})\end{array}$ & $\begin{array}{c}\text { EU WAC } \\
\text { Inert }\end{array}$ & $\begin{array}{l}\text { EU WAC } \\
\text { non-haz }\end{array}$ & $\begin{array}{c}\text { EU WAC } \\
\text { haz }\end{array}$ \\
\hline As & 31 & 0.0044 & 0.0008 & 0.018 & 0.0032 & 0.1 & 0.4 & 6 \\
\hline$\overline{\mathrm{Cd}}$ & 31 & 0.00039 & 0.00006 & 0.0022 & 0.00036 & 0.03 & 0.6 & 3 \\
\hline Chloride & 29 & 140 & 130 & 170 & 140 & 550 & 10000 & 17000 \\
\hline $\mathrm{Cr}$ & 30 & 0.0025 & 0.0006 & 0.0078 & 0.0016 & 0.2 & 4 & 25 \\
\hline $\mathrm{Cu}$ & 31 & 0.012 & 0.0018 & 0.036 & 0.0090 & 0.9 & 25 & 50 \\
\hline $\mathrm{Ni}$ & 31 & 0.0035 & 0.0002 & 0.014 & 0.0026 & 0.2 & 5 & 20 \\
\hline $\mathrm{Pb}$ & 31 & 0.0043 & 0.0006 & 0.022 & 0.0024 & 0.2 & 5 & 25 \\
\hline Sulphate & 31 & 27 & 2.4 & 110 & 16 & 560 & 10000 & 25000 \\
\hline $\mathrm{Zn}$ & 31 & 0.039 & 0.02 & 0.19 & 0.020 & 2 & 25 & 90 \\
\hline
\end{tabular}

\begin{tabular}{|c|c|c|c|c|c|c|c|c|}
\hline EluateParameter & $\begin{array}{c}\text { No of } \\
\text { Samples }\end{array}$ & $\begin{array}{c}\text { Avg } \\
(\mathrm{mg} / \mathrm{kg})\end{array}$ & $\begin{array}{c}\text { Min } \\
(\mathrm{mg} / \mathrm{kg})\end{array}$ & $\begin{array}{c}\text { Max } \\
(\mathrm{mg} / \mathrm{kg})\end{array}$ & $\begin{array}{l}\text { Median } \\
(\mathrm{mg} / \mathrm{kg})\end{array}$ & $\begin{array}{c}\text { EU WAC } \\
\text { Inert }\end{array}$ & $\begin{array}{l}\text { EU WAC } \\
\text { non-haz }\end{array}$ & $\begin{array}{c}\text { EU WAC } \\
\text { haz }\end{array}$ \\
\hline As & 30 & 0.0045 & 0.0008 & 0.018 & 0.0036 & 0.1 & 0.4 & 6 \\
\hline$\overline{\mathrm{Cd}}$ & 18 & 0.00049 & 0.00006 & 0.0022 & 0.00035 & 0.03 & 0.6 & 3 \\
\hline Chloride & 29 & 140 & 130 & 170 & 140 & 550 & 10000 & 17000 \\
\hline $\mathrm{Cr}$ & 28 & 0.0026 & 0.0006 & 0.0078 & 0.0017 & 0.2 & 4 & 25 \\
\hline $\mathrm{Cu}$ & 31 & 0.012 & 0.0018 & 0.036 & 0.0090 & 0.9 & 25 & 50 \\
\hline $\mathrm{Ni}$ & 25 & 0.004 & 0.0004 & 0.014 & 0.0038 & 0.2 & 5 & 20 \\
\hline $\mathrm{Pb}$ & 27 & 0.0048 & 0.0006 & 0.022 & 0.0032 & 0.2 & 5 & 25 \\
\hline Sulphate & 31 & 27 & 2.4 & 110 & 16 & 560 & 10000 & 25000 \\
\hline $\mathrm{Zn}$ & 8 & 0.082 & 0.022 & 0.19 & 0.056 & 2 & 25 & 90 \\
\hline
\end{tabular}

Statistics for Parameter value (for upper table)

\begin{tabular}{|l|c|r|r|}
\hline Parameter & $\begin{array}{c}\text { No of } \\
\text { Samples }\end{array}$ & \multicolumn{1}{c|}{ Min } & \multicolumn{1}{c|}{ Max } \\
\hline $\mathrm{pH}$ & 31 & 5.6 & 7.2 \\
\hline
\end{tabular}




\section{Batch leaching test}

Uncontaminated Soil

Leached amount

L/S= $10 \mathrm{l} / \mathrm{kg}$

\begin{tabular}{|c|c|c|c|c|c|c|c|c|}
\hline EluateParameter & $\begin{array}{c}\text { No of } \\
\text { Samples }\end{array}$ & $\begin{array}{c}\text { Avg } \\
(\mathrm{mg} / \mathrm{kg})\end{array}$ & $\begin{array}{c}\text { Min } \\
(\mathrm{mg} / \mathrm{kg})\end{array}$ & $\begin{array}{c}\text { Max } \\
(\mathrm{mg} / \mathrm{kg})\end{array}$ & $\begin{array}{l}\text { Median } \\
(\mathrm{mg} / \mathrm{kg})\end{array}$ & $\begin{array}{c}\text { EU WAC } \\
\text { Inert }\end{array}$ & $\begin{array}{l}\text { EU WAC } \\
\text { non-haz }\end{array}$ & $\begin{array}{c}\text { EU WAC } \\
\text { haz }\end{array}$ \\
\hline As & 2 & 0.042 & 0.013 & 0.071 & 0.042 & 0.5 & 2 & 25 \\
\hline $\mathrm{Cd}$ & 2 & 0.002 & 0.002 & 0.002 & 0.0020 & 0.04 & 1 & 5 \\
\hline Chloride & 1 & 740 & 740 & 740 & 740 & 800 & 15000 & 25000 \\
\hline $\mathrm{Cr}$ & 2 & 0.017 & 0.015 & 0.018 & 0.017 & 0.5 & 10 & 70 \\
\hline $\mathrm{Cu}$ & 2 & 0.056 & 0.049 & 0.062 & 0.056 & 2 & 50 & 100 \\
\hline $\mathrm{Ni}$ & 2 & 0.01 & 0.01 & 0.011 & 0.010 & 0.4 & 10 & 40 \\
\hline $\mathrm{Pb}$ & 2 & 0.029 & 0.02 & 0.038 & 0.029 & 0.5 & 10 & 50 \\
\hline Sulphate & 2 & 36 & 27 & 45 & 36 & 1000 & 20000 & 50000 \\
\hline $\mathrm{Zn}$ & 2 & 0.37 & 0.2 & 0.54 & 0.37 & 4 & 50 & 200 \\
\hline
\end{tabular}

Statistics EXCLUDING measurements below detection limit

\begin{tabular}{|c|c|c|c|c|c|c|c|c|}
\hline EluateParameter & $\begin{array}{c}\text { No of } \\
\text { Samples }\end{array}$ & $\begin{array}{c}\text { Avg } \\
(\mathrm{mg} / \mathrm{kg})\end{array}$ & $\begin{array}{c}\text { Min } \\
(\mathrm{mg} / \mathrm{kg})\end{array}$ & $\begin{array}{c}\text { Max } \\
(\mathrm{mg} / \mathrm{kg})\end{array}$ & $\begin{array}{l}\text { Median } \\
\text { (mg/kg) }\end{array}$ & $\begin{array}{c}\text { EU WAC } \\
\text { Inert }\end{array}$ & $\begin{array}{l}\text { EU WAC } \\
\text { non-haz }\end{array}$ & \begin{tabular}{|c|} 
EU WAC \\
haz
\end{tabular} \\
\hline As & 2 & 0.042 & 0.013 & 0.071 & 0.042 & 0.5 & 2 & 25 \\
\hline \begin{tabular}{|l} 
Chloride \\
\end{tabular} & 1 & 740 & 740 & 740 & 740 & 800 & 15000 & 25000 \\
\hline $\mathrm{Cr}$ & 2 & 0.017 & 0.015 & 0.018 & 0.017 & 0.5 & 10 & 70 \\
\hline $\mathrm{Cu}$ & 2 & 0.056 & 0.049 & 0.062 & 0.056 & 2 & 50 & 100 \\
\hline $\mathrm{Pb}$ & 2 & 0.029 & 0.02 & 0.038 & 0.029 & 0.5 & 10 & 50 \\
\hline Sulphate & 2 & 36 & 27 & 45 & 36 & 1000 & 20000 & 50000 \\
\hline$\overline{Z n}$ & 1 & 0.54 & 0.54 & 0.54 & 0.54 & 4 & 50 & 200 \\
\hline
\end{tabular}

Statistics for Parameter value (for upper table)
\begin{tabular}{|l|c|c|c|}
\hline Parameter & $\begin{array}{c}\text { No of } \\
\text { Samples }\end{array}$ & \multicolumn{1}{|c|}{ Min } & Max \\
\hline $\mathrm{pH}$ & 2 & 6.4 & 6.6 \\
\hline
\end{tabular}

